\title{
Aerosol size distribution and new particle formation in the western Yangtze River Delta of China: 2 years of measurements at the SORPES station
}

\author{
X. M. Qi ${ }^{1,3}$, A. J. Ding ${ }^{1,3}$, W. Nie ${ }^{1,3}$, T. Petäjä ${ }^{2}$, V.-M. Kerminen ${ }^{2}$, E. Herrmann ${ }^{1, a}$, Y. N. Xie ${ }^{1}$, L. F. Zheng ${ }^{1,3}$, \\ H. Manninen ${ }^{2}$, P. Aalto ${ }^{2}$, J. N. Sun ${ }^{1,3}$, Z. N. Xu ${ }^{1,3}$, X. G. Chi ${ }^{1,3}$, X. Huang ${ }^{1,3}$, M. Boy ${ }^{2,3}$, A. Virkkula ${ }^{1,2,3}$, X.-Q. Yang ${ }^{1,3}$, \\ C. B. Fu ${ }^{1,3}$, and M. Kulmala ${ }^{2}$ \\ ${ }^{1}$ Institute for Climate and Global Change Research \& School of Atmospheric Sciences, Nanjing University, 210023, \\ Nanjing, China \\ ${ }^{2}$ Department of Physics, University of Helsinki, 00014 Helsinki, Finland \\ ${ }^{3}$ Collaborative Innovation Center of Climate Change, Nanjing, Jiangsu Province, China \\ ${ }^{a}$ now at: Laboratory for Atmospheric Chemistry, Paul Scherrer Institute, Switzerland
}

Correspondence to: A. J. Ding (dingaj@nju.edu.cn)

Received: 30 January 2015 - Published in Atmos. Chem. Phys. Discuss.: 29 April 2015

Revised: 1 September 2015 - Accepted: 16 October 2015 - Published: 10 November 2015

\begin{abstract}
Aerosol particles play important roles in regional air quality and global climate change. In this study, we analyzed 2 years (2011-2013) of measurements of submicron particles $(6-800 \mathrm{~nm})$ at a suburban site in the western Yangtze River Delta (YRD) of eastern China. The number concentrations (NCs) of particles in the nucleation, Aitken and accumulation modes were $5300 \pm 5500,8000 \pm 4400$, $5800 \pm 3200 \mathrm{~cm}^{-3}$, respectively. The NCs of total particles are comparable to those at urban/suburban sites in other Chinese megacities, such as Beijing, but about 10 times higher than in the remote western China. Long-range and regional transport largely influenced number concentrations and size distributions of submicron particles. The highest and lowest accumulation-mode particle number concentrations were observed in air masses from the YRD and coastal regions, respectively. Continental air masses from inland brought the highest concentrations of nucleation-mode particles. New particle formation (NPF) events, apparent in $44 \%$ of the effective measurement days, occurred frequently in all the seasons except winter. The frequency of NPF in spring, summer and autumn is much higher than other measurement sites in China. Sulfuric acid was found to be the main driver of NPF events. The particle formation rate was the highest in spring $\left(3.6 \pm 2.4 \mathrm{~cm}^{-3} \mathrm{~s}^{-1}\right)$, whereas the particle growth rate had the highest values in summer $\left(12.8 \pm 4.4 \mathrm{~nm} \mathrm{~h}^{-1}\right)$. The formation rate was typically high in relatively clean air masses,
\end{abstract}

whereas the growth rate tended to be high in the polluted YRD air masses. The frequency of NPF events and the particle growth rates showed a strong year-to-year difference. In the summer of 2013, associated with a multi-week heat wave and strong photochemical processes, NPF events occurred with larger frequency and higher growth rates compared with the same period in 2012. The difference in the location and strength of the subtropical high pressure system, which influences the air mass transport pathways and solar radiation, seems to be the cause for year-to-year differences. This study reports, up to now, the longest continuous measurement records of submicron particles in eastern China and helps to achieve a comprehensive understanding of the main factors controlling the seasonal and year-to-year variation of the aerosol size distribution and NPF in this region.

\section{Introduction}

Atmospheric aerosols affect human life by influencing both air quality and climate (e.g., Charlson et al., 1992; Menon et al., 2002; Akimoto, 2003; Heal et al., 2012; IPCC, 2013). Fine particles, especially the submicron ones, have received lots of attention due to their close connection to climate via light extinction (Malm et al., 1994), cloud droplet activa- 
tion (Kerminen et al., 2005; Wiedensohler et al., 2009; Sihto et al., 2011) and precipitation formation (Gettelman et al., 2013; Lebo and Feingold, 2014), as well as due to their adverse effects on human health (Pope et al., 2002; Rao et al., 2012).

Numerous studies have been conducted all over the world focusing on the characters of submicron particles, including their chemical composition and size distribution as well as their formation and growth in the atmosphere (e.g., Woo et al., 2001; Birmili et al., 2003; Engler et al., 2007; Zhang et al., 2007; Dal Maso et al., 2008; Laakso et al., 2008; Jimenez et al., 2009; Komppula et al., 2009; Asmi et al., 2011; Kerminen et al., 2012; Vakkari et al., 2013; Kulmala et al., 2014; Nie et al., 2014; Nieminen et al., 2014). In China, studies on submicron particles started about a decade ago. However, to the best of our knowledge, there are only three studies in China providing more than 1 year of measurements of aerosol size distributions, two of them conducted in the North China Plain (Wu et al., 2007; Shen et al., 2011) and one at Mount Waliguan in remote western China (Kivekäs et al., 2009). Therefore, knowledge about the temporal variation of submicron particles and their relationship to meteorology and human activities in China is rather poor, even in some well-developed regions such as Yangtze River Delta (YRD) in eastern China.

The YRD has experienced rapid urbanization and industrialization in the last 2 decades, which have induced large amounts of fossil fuel consumption in the region and resulted in serious air pollution (Chameides et al., 2002; Ding et al., 2013a, b; Tie and Cao, 2009; Li et al., 2011). In addition, the YRD is a region influenced by typical Asian monsoons, which dominate the temporal and spatial variations of particles (Qian et al., 2003; Ding et al., 2013a). However, previous studies on aerosols in this region were mainly on mass concentrations and chemical compositions (e.g., Huang et al., 2012; Cheng et al., 2013; Ding et al., 2013a); studies on the number concentrations and size distributions were rather limited. In Nanjing, Herrmann et al. (2014) reported the first result of about 4 months of data on aerosol size distribution at the SORPES (Station for Observing Regional Processes of the Earth System) station, a suburban site in Nanjing, and Wang et al. (2014) reported about 1 month of data at another suburban site. Both studies were conducted during the cold season. In other regions of the YRD, Gao et al. (2009) reported an intensive campaign in the early summer of 2005 in Taicang, a small town near to Shanghai, and Du et al. (2012) reported wintertime measurements from October 2008 to February 2009 in Shanghai. These results showed significant differences in both the diurnal patterns and NPF (new particle formation) characteristics between the two seasons and emphasize the need of continuous long-term measurements on the number size distributions of submicron particles in this region.

In the present study, we report 2 years of continuous observation of submicron particles $(6-800 \mathrm{~nm})$ and related quan- tities (including trace gases, $\mathrm{PM}_{2.5}$ mass concentration and meteorological data) recorded at the SORPES site in suburban Nanjing in the western part of the YRD from December 2011 to November 2013. The aim of this work is to characterize the temporal variations of particle number size distributions and occurrence of NPF in the western part of the YRD, and to improve our understanding of the sources and processes influencing the atmospheric aerosol population in the developed region of China.

\section{Experiment and methodology}

\subsection{Site information and measurements}

This study was conducted at the SORPES station developed in 2011 (Ding et al., 2013a). The site is located about $20 \mathrm{~km}$ northeast of downtown Nanjing $\left(118^{\circ} 57^{\prime} 10^{\prime \prime} \mathrm{E}, 32^{\circ} 07^{\prime} 14^{\prime \prime} \mathrm{N}\right.$, $40 \mathrm{~m}$ above ground level). With few local sources within its $2-3 \mathrm{~km}$ surroundings, it can be considered as a regional background site in the well-developed YRD of eastern China. More details of the site, including trace gas, $\mathrm{PM}_{2.5}$ and meteorological measurements, can be found in Ding et al. (2013a).

The size distribution of submicron particles is measured with a DMPS (differential mobility particle sizer) constructed at the University of Helsinki in Finland. This instrument was also involved in the instrument intercomparison workshops conducted within the European infrastructure project EUSAAR (European Supersites for Atmospheric Aerosol Research) and ACTRIS (Aerosols, Clouds, and Trace gases Research Infrastructure Network) (Wiedensohler et al., 2012). Before entering the inlet of the instrument, the particles are cut off at $2.5 \mu \mathrm{m}$ and then dried (using a Nafion tube from December 2011 to June 2012 and silica gel dryer after June 2012). The instrument consists of one DMA (differential mobility analyzer) in different flow rates and one CPC (condensation particle counter, TSI Model 3772). The DMA segregates the particles into exact narrow size ranges based on different narrow ranges of electrical mobility of charged particles in the electrical field. Equilibrium charge is ensured by two americium 241 sources (each about $37 \mathrm{kBq}$ ) before particles enter the DMA. The DMPS is a flow-switching-type differential mobility particle sizer in which two different sample and sheath air flow rates for the DMA are used to cover a wide size range. In the high flow mode, the sample air and sheath air flows are 3 and $20 \mathrm{~L} \mathrm{~min}^{-1}$, respectively, and in the low flow mode they are 1 and $5 \mathrm{~L} \mathrm{~min}^{-1}$, respectively. The high flow mode measures the size from 6 to $100 \mathrm{~nm}$ and the low flow mode measures from 100 to $800 \mathrm{~nm}$. The measurement time interval of the instrument is $10 \mathrm{~min}$ during which the total particle number concentration is measured by CPC directly and 29 channels (16 for low flow rate and 13 for high flow rate) are scanned. Weekly maintenance, including flow rate adjusting and im- 
pactor cleaning, is routinely performed. The data assimilation in two flow modes and the test of data quality are described in Appendix A.

\subsection{Calculation of variables characterizing new particle formation}

The calculation of particle growth and formation rates along with the condensation sink were made following the procedure described by Kulmala et al. (2012). The growth rate (GR) of particles during the NPF events can be expressed as

$\mathrm{GR}=\frac{\mathrm{d} d_{\mathrm{p}}}{\mathrm{d} t}=\frac{\Delta d_{\mathrm{p}}}{\Delta t}=\frac{d_{\mathrm{p} 2}-d_{\mathrm{p} 1}}{t_{2}-t_{1}}$,

where $d_{\mathrm{p} 1}$ and $d_{\mathrm{p} 2}$ are the representative of the diameter of nucleated particles at the times $t_{1}$ and $t_{2}$, respectively. For calculation, $d_{\mathrm{p} 1}$ and $d_{\mathrm{p} 2}$ are defined as the center of the size bin and $t_{1}$ and $t_{2}$ are the times when the concentration of this size bin reaches the maximum.

The formation rate of particles of diameter $d_{\mathrm{p}}$ is obtained from

$J_{d_{\mathrm{p}}}=\frac{\mathrm{d} N_{d_{\mathrm{p}}}}{\mathrm{d} t}+\operatorname{CoagS}_{d_{\mathrm{p}}} \times N_{d_{\mathrm{p}}}+\frac{\mathrm{GR}}{\Delta d_{\mathrm{p}}} \times N_{d_{\mathrm{p}}}+S_{\text {losses }}$,

where the first term on the right side is the time evolution of the particle number concentration in the size range $\left[d_{\mathrm{p}}, d_{\mathrm{p}}+\right.$ $\left.\Delta d_{\mathrm{p}}\right]$. The second term is the coagulation loss approximated by the product of coagulation sink $\left(\mathrm{CoagS}_{d_{\mathrm{p}}}\right)$ and the number concentration in the size range $\left[d_{\mathrm{p}}, d_{\mathrm{p}}+\Delta d_{\mathrm{p}}\right]$. The third term is the growth out of the considered size range where GR is the observed growth rate. The fourth term represents additional losses which were not considered in this study.

Having positive correlation with the coagulation sink (CoagS), the condensation sink (CS) describes the speed at which condensable vapor molecules condense onto the existing aerosol. It is expressed as

$$
\begin{aligned}
\mathrm{CS} & =4 \pi \int_{0}^{d_{\mathrm{p}} \max } \beta_{m}\left(d_{\mathrm{p}}^{\prime}\right) d_{\mathrm{p}}^{\prime} N_{d_{\mathrm{p}}^{\prime}} \mathrm{d} d_{\mathrm{p}}^{\prime} \\
& =4 \pi D \sum_{d_{\mathrm{p}}^{\prime}} \beta_{m, d_{\mathrm{p}}^{\prime}} d_{\mathrm{p}}^{\prime} N_{d_{\mathrm{p}}^{\prime}},
\end{aligned}
$$

where $D$ is the diffusion coefficient of the condensing vapor, $\beta_{m}$ is a transition-regime correction, $d^{\prime} \mathrm{p}$ is the discrete diameter and $N_{d^{\prime} \mathrm{p}}$ is the particle number concentration in respective size bin. The increase of CS due to the particle hygroscopic growth was also estimated. The hygroscopic growth factor (GF), i.e., the ratio of the particle diameter at an ambient relative humidity $(\mathrm{RH})$ to the corresponding "dry" particle diameter, was determined using the method described by Laakso et al. (2004),

$\mathrm{GF}=\left(1-\frac{\mathrm{RH}}{100}\right)^{\gamma\left(\mathrm{d}_{\mathrm{p}}\right)}$.
Here $\gamma\left(d_{\mathrm{p}}\right)$ depends on the particle diameter $\left(d_{\mathrm{p}}\right)$ and was obtained by a least square fit to hygroscopicity data. As there were no measured hygroscopic growth data at the SORPES station, the hygroscopicity data from another site in the north of downtown Nanjing (Wu et al., 2014) was used.

Sulfuric acid has been identified as the main factor of new particle formation (Kulmala et al., 2013). Therefore, in this study we used the semi-empirical equation constructed by Mikkonen et al. (2011) to calculate the sulfuric acid proxy:

$$
\begin{gathered}
{\left[\mathrm{H}_{2} \mathrm{SO}_{4}\right]=1.30 \times 10^{-1} \cdot k \cdot \text { Radiation }^{1.10} \cdot\left[\mathrm{SO}_{2}\right]^{0.69}} \\
\cdot \mathrm{CS}^{-0.53} \cdot \mathrm{RH}^{-1.92}
\end{gathered}
$$

where $k$ is the reaction rate constant.

\section{Results and discussions}

\subsection{Particle number concentrations and size distributions}

\subsubsection{Overall results}

Figure 1a shows the averaged particle number size distribution during the studied period. It shows a typical multimodal distribution as a result of combining of three lognormal distributions in the nucleation $(6-30 \mathrm{~nm})$, Aitken $(30$ $100 \mathrm{~nm})$ and accumulation modes $(100-800 \mathrm{~nm})$. Figure $1 \mathrm{~b}$ illustrates the average fraction of the particle number, surface and volume concentration in these three modes. It shows features similar to most other continental regions in the lower troposphere, i.e., the nucleation- and Aitken-mode particles $(<100 \mathrm{~nm})$ dominate the number concentration, and the accumulation-mode particles control the surface and volume concentration (Raes et al., 2000; Asmi et al., 2011).

As shown in Table 1, the average total particle number concentration (NC) over the diameter range $6-800 \mathrm{~nm}$ during the 2-year period was $19200 \pm 9200 \mathrm{~cm}^{-3}$, with the values of $5300 \pm 5500 \mathrm{~cm}^{-3}$ in the nucleation mode $(6-30 \mathrm{~nm})$, $8000 \pm 4400 \mathrm{~cm}^{-3}$ in the Aitken mode $(30-100 \mathrm{~nm})$ and $5800 \pm 3200 \mathrm{~cm}^{-3}$ in the accumulation mode $(100-800 \mathrm{~nm})$, respectively. The NCs of total particles at SORPES in Nanjing are comparable to those measured at the urban site (about $32700 \mathrm{~cm}^{-3}$ in the size range of $3-1000 \mathrm{~nm}$ ) (Wu et al., 2008) and at a rural site in Beijing (about $11500 \mathrm{~cm}^{-3}$ in the size range of 3-1000 nm) (Shen et al., 2011), while about 10 times higher than those measured at Mount Waliguan, a remote background site in western China (about $2100 \mathrm{~cm}^{-3}$ in the size range of $12-570 \mathrm{~nm}$ ) (Kivekäs et al., 2009). One typical feature at SORPES is the high concentration of accumulation-mode particles, which can be up to several times the typical concentrations measured in Europe or North America (200-2900 $\mathrm{cm}^{-3}$ compared to $5700 \mathrm{~cm}^{-3}$ at SORPES in the size range of $100-500 \mathrm{~nm}$ ) (Stanier et al., 2004; Asmi et al., 2011; Wang et al., 2011). 
Table 1. Overall statistics for the number concentrations and relevant parameters calculated based on DMPS measurement at the SORPES site during December 2011-November 2013.

\begin{tabular}{llllll}
\hline & Annual & Spring & Summer & Autumn & Winter \\
\hline Total particles $\left(\mathrm{cm}^{-3}\right)$ & $19200^{\mathrm{a}} \pm 9200^{\mathrm{b}}$ & $20600 \pm 9000$ & $18000 \pm 10800$ & $18000 \pm 7600$ & $19900 \pm 9300$ \\
Nucleation mode $\left(\mathrm{cm}^{-3}\right)$ & $5300 \pm 5500$ & $6200 \pm 5900$ & $4600 \pm 5500$ & $4800 \pm 4900$ & $5700 \pm 5400$ \\
Aitken mode $\left(\mathrm{cm}^{-3}\right)$ & $8000 \pm 4400$ & $8500 \pm 4000$ & $8100 \pm 5700$ & $7600 \pm 3900$ & $7800 \pm 3900$ \\
Accumulation mode $\left(\mathrm{cm}^{-3}\right)$ & $5800 \pm 3200$ & $5900 \pm 2900$ & $5300 \pm 4200$ & $5600 \pm 2500$ & $6500 \pm 3000$ \\
AMD $6-800 \mathrm{~nm}(\mathrm{~nm})$ & $92 \pm 25$ & $89 \pm 23$ & $90 \pm 26$ & $92 \pm 26$ & $97 \pm 26$ \\
$\mathrm{CS}\left(10^{-2} \mathrm{~s}^{-1}\right)$ & $3.8 \pm 2.0$ & $4.0 \pm 1.7$ & $3.5 \pm 2.5$ & $3.6 \pm 1.7$ & $4.2 \pm 1.9$ \\
$\mathrm{CS}_{\mathrm{wet}}\left(10^{-2} \mathrm{~s}^{-1}\right)$ & $5.3 \pm 2.9$ & $5.5 \pm 2.6$ & $5.0 \pm 3.7$ & $5.1 \pm 2.7$ & $5.8 \pm 2.7$ \\
\hline
\end{tabular}

${ }^{a}$ Mean; ${ }^{b}$ standard deviation; $\mathrm{AMD}_{6-800 \mathrm{~nm}}$ : arithmetic mean diameter of 6-800 nm particles; CS: condensation sink; $\mathrm{CS}_{\mathrm{wet}}$ : condensation sink with the consideration of hygroscopic growth.
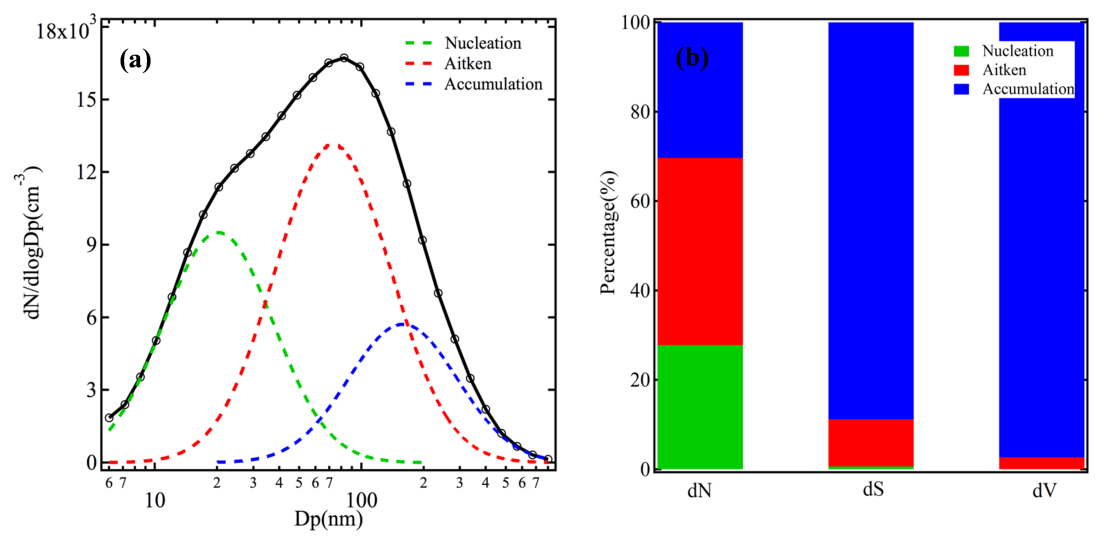

Figure 1. (a) Averaged number size distribution and lognormal fitting curves of three modes, and (b) averaged fraction of the particles number, surface and volume concentrations in the three modes measured at the SORPES site during December 2011-November 2013.

\subsubsection{Seasonal variations}

The average seasonal variations of particle number concentrations during the 2 years of measurements are presented in Fig. 2. Nucleation-mode particles had the highest concentrations in winter (December-January) and spring (April). Aitken-mode particles showed similar patterns with an additional peak in July. Accumulation-mode particles showed high concentrations in January and June and low concentrations in July, which is similar to the seasonal variation of $\mathrm{PM}_{2.5}$ concentrations reported by Ding et al. (2013a). Accounting for almost $70 \%$ of the total particles, the nucleation- and Aitken-mode particles dominated the seasonal cycle of the total particle number concentration. The exact values and standard deviations of the particle number concentrations in spring (March-May), summer (June-August), autumn (September-November) and winter (December-February) are given in Table 1. Seasonally, the nucleation- and Aitken-mode particles showed the highest concentrations in spring $\left(6200 \mathrm{~cm}^{-3} \pm 5900 \mathrm{~cm}^{-3}\right.$ and $8500 \mathrm{~cm}^{-3} \pm 4000 \mathrm{~cm}^{-3}$, respectively), whereas the highest concentrations of accumulation-mode particles were observed in winter $\left(6500 \mathrm{~cm}^{-3} \pm 3000 \mathrm{~cm}^{-3}\right)$. The arithmetic mean diameter (AMD) of the particles and condensation sink (CS) revealed also seasonal cycles (Table 1), with the highest values observed in winter $\left(\mathrm{AMD}_{6-800 \mathrm{~nm}}\right.$ : $97 \mathrm{~nm} \pm 26 \mathrm{~nm}, \quad$ CS: $4.2 \times 10^{-2} \mathrm{~s}^{-1} \pm 1.9 \times 10^{-2} \mathrm{~s}^{-1}$, $\mathrm{CS}_{\mathrm{wet}}: 5.8 \times 10^{-2} \mathrm{~s}^{-1} \pm 2.7 \times 10^{-2} \mathrm{~s}^{-1}$ ). Given that the hygroscopicity measurements were conducted at another site in Nanjing (Wu et al., 2014), the hygroscopic growth associated with the calculation of CS at the SORPES station might have large uncertainties. We therefore deployed the CS without considering the hygroscopic growth in the following discussion.

Generally, the seasonal patterns of NCs of submicron particles at SORPES were related to the long-range transport associated with the Asian monsoon climate and also anthropogenic emissions. Figure 3 presents the seasonal variations of four meteorological variables (temperature, pressure, radiation and rainfall) during the 2-year measurement period. In winter, few rains and a low boundary layer favor the accumulation of pollutants and result in high particle loadings. In addition, the winter heating in northern China would bring aged accumulation-mode particles to Nanjing via the regional transports (Zhang et al., 2009; Li et al., 2011). In summer, the predominantly rainy and unstable weather (e.g., 

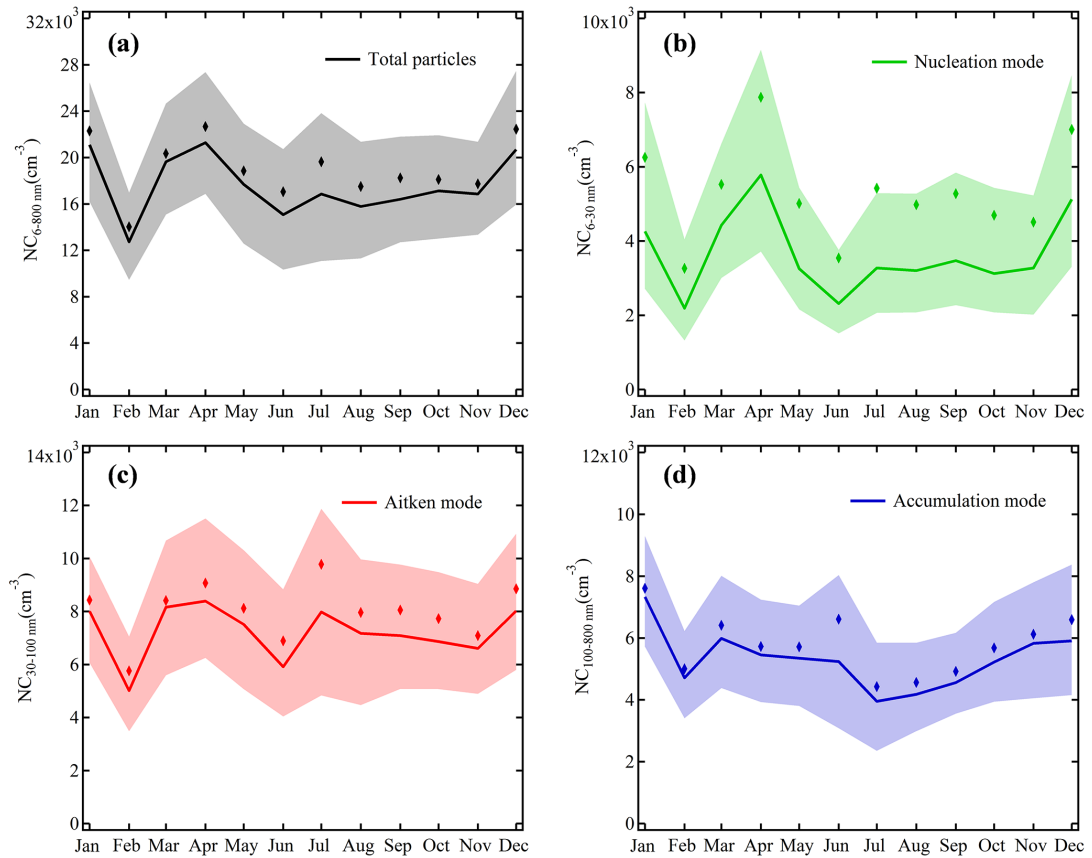

Figure 2. The averaged seasonal variations of (a) the total particle number concentration and number concentrations in the (b) nucleation, (c) Aitken and (d) accumulation modes. Note: bold solid lines are the monthly medians and shaded areas represent the 25 th-75th percentile range. The diamond markers represent the monthly average.
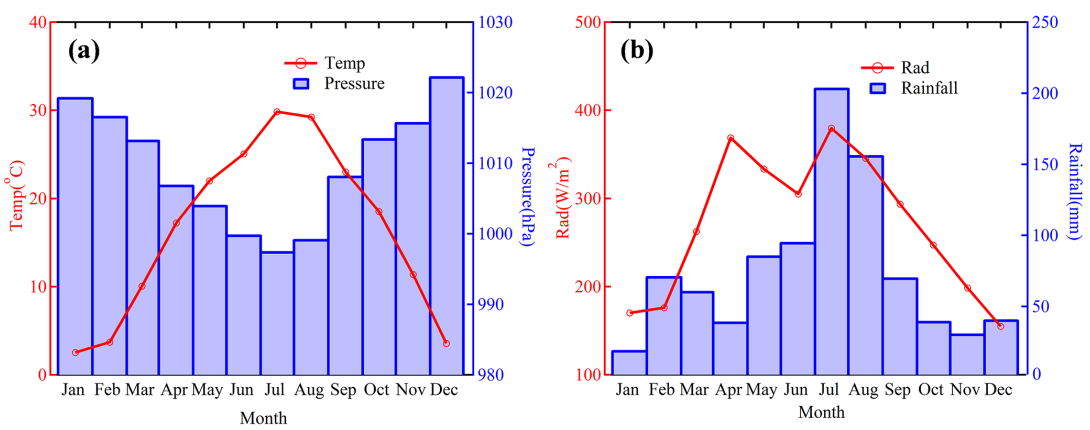

Figure 3. Averaged seasonal variations of (a) temperature and pressure and (b) radiation and rainfall during the entire measurement period.

convection and monsoon precipitation) leads to low particle number concentrations, especially for accumulation-mode particles. Radiation, which drives NPF events, influences the NCs of nucleation and Aitken-mode particles. Moreover, an evident holiday effect can also influence the observed temporal variation. For example, the low particle loadings in all the modes can be identified in February (see Fig. 2) when the Chinese have the winter break to celebrate the Spring Festival (Ding et al., 2013a).

Biomass burning (BB) is an important source of accumulation-mode particles in early summer (Ding et al., 2013a, b), so the burning of wheat straw in northern and middle parts of eastern China (Wu et al., 2008; Shen et al., 2011) is the plausible cause for the particle NCs peak observed in June (Fig. 2d). Here, we defined BB events as potassium con- centration $\mathrm{K}^{+}>2 \mu \mathrm{g} \mathrm{cm}^{-3}$ and $\mathrm{K}^{+} / \mathrm{PM}_{2.5}$ ratio $>0.02\left(\mathrm{~K}^{+}\right.$ was measured using MARGA; Nie et al., 2015). The average $\mathrm{NC}$ of accumulation-mode particles during BB events in June was $31700 \mathrm{~cm}^{-3}$, which is almost 6 times higher than the corresponding $\mathrm{NC}$ in non-BB event days $\left(5300 \mathrm{~cm}^{-3}\right)$. Relatively large $(>100 \mathrm{~nm})$ particles are emitted directly from BB (Reid et al., 2005; Li et al., 2007), or formed rapidly after emissions by the combination of NPF and various particle growth processes (Hennigan et al., 2012; Vakkari et al., 2014). Such particles are able to promote atmospheric heterogeneous chemistry by providing a large surface area (Nie et al., 2015), influence the global climate by enhancing the cloud condensation nuclei capacity (Hennigan et al., 2012), and even change the everyday weather (Ding et al., 2013b). 

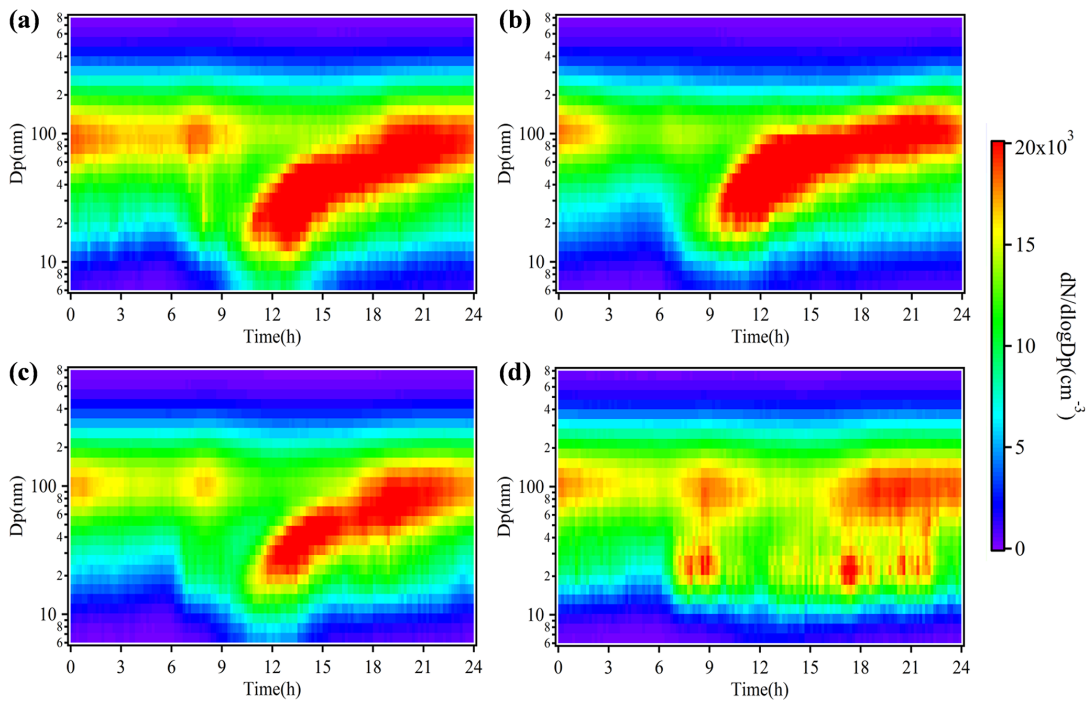

Figure 4. Averaged diurnal cycles of particle number size distributions for (a) spring, (b) summer, (c) autumn and (d) winter at the SORPES station during the 2-year measurement period.

\subsubsection{Diurnal pattern in different seasons}

The diurnal cycles of particle number size distributions had similar patterns in spring, summer and autumn, which were connected to the events of new particle formation and growth, showing the typical "banana" shape during daytime (Fig. 4a-c). However, obvious differences could be observed for the starting time and strength of NPF in different seasons. It needs to be pointed out that in the averaged diurnal pattern in spring, summer and autumn (Fig. 4a-c) the NPF had a relatively low number concentration of $6-15 \mathrm{~nm}$ particles, which is different from a typical NPF event. The main reason for this feature is that the averaged patterns include both event and non-event days and that sub- $100 \mathrm{~nm}$ particles tend to grow also during non-event days without a clear formation of new sub- $15 \mathrm{~nm}$ particles. A detailed discussion on NPF events will be given in Sect. 3.2. Compared with other seasons, the high peaks of NCs around 20-30 and $100 \mathrm{~nm}$ during the wintertime rush hours in the morning and late afternoon (Fig. 4d) suggest that local combustion sources, such as vehicle emissions, played a more important role in the diurnal cycle of the total particle concentration than sources like regional NPF and growth.

In order to investigate the detailed diurnal variations of the particle NCs in different modes, we compared the diurnal patterns of the three modes in seasons: spring and winter (Fig. 5a-c). For nucleation-mode particles, peak concentrations appeared at noontime in spring but in the early morning or late afternoon in winter (Fig. 5a). The later suggests a possible influence from human activities, such as vehicle emissions under conditions of a low mixing layer. For the Aitken-mode particles, in spring the highest concentrations were seen about $2 \mathrm{~h}$ after the appearance of the peak in the nucleation mode, which was due to the growth of nucleated particles to larger sizes (Fig. 5b). In winter, Aitken-mode particles had peaks at the same time or a bit later than the nucleation-mode particles did. The diurnal variation of the accumulation-mode particle number concentration (Fig. 5c) was controlled by the development of the boundary layer in both seasons, having a pattern similar to that of the $\mathrm{PM}_{2.5}$ concentration (Ding et al., 2013a).

\subsubsection{The influences of air masses}

Figure 6 shows backward trajectory cluster analysis for the SORPES site. Using the Hybrid Single-Particle Lagrangian Integrated Trajectory (HYSPLIT) model version 4.9 (Draxler and Hess, 1998) driven with Global Data Assimilation System (GDAS) output, five clusters of trajectories were identified based on hourly 3-day backward trajectories for the period of December 2011-November 2013. Here we calculated the trajectories for 3 days by considering a rough turnover time of about 2.4 days for $200 \mathrm{~nm}$ particles (Tunved et al., 2005). The results showed that air masses arriving at the SORPES site generally came from the inland continent $(14.8 \%$ of the air masses belonging to the cluster $\mathrm{C} 2$ and $13.0 \%$ to the cluster $\mathrm{C} 3$ ), coastal northern China (C1: $30.6 \%, \mathrm{C} 4$ and $\mathrm{C} 5$ together: $41.6 \%$ in total). The two continental air masses had distinguished source regions, C2 passed over the North China Plain and C3 traveled over a large area of BVOCs (biogenic volatile organic compounds). For the coastal air masses, C5 was much more local compared to $\mathrm{C} 4$, but the latter just crossed the city cluster along Nanjing-Shanghai axis and might have an additional marine signature. The air mass transport pattern was controlled by the Asian monsoon (Ding et al., 2013a), with the winter mon- 

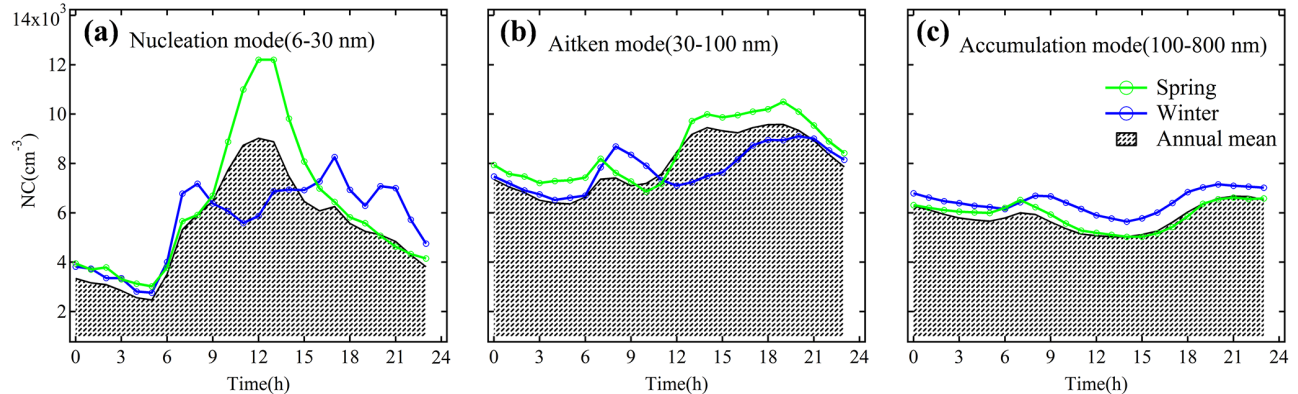

Figure 5. Averaged diurnal variations of particle number concentrations in (a) nucleation mode, (b) Aitken mode and (c) accumulation mode in spring, winter and the entire period during the 2-year measurement period.
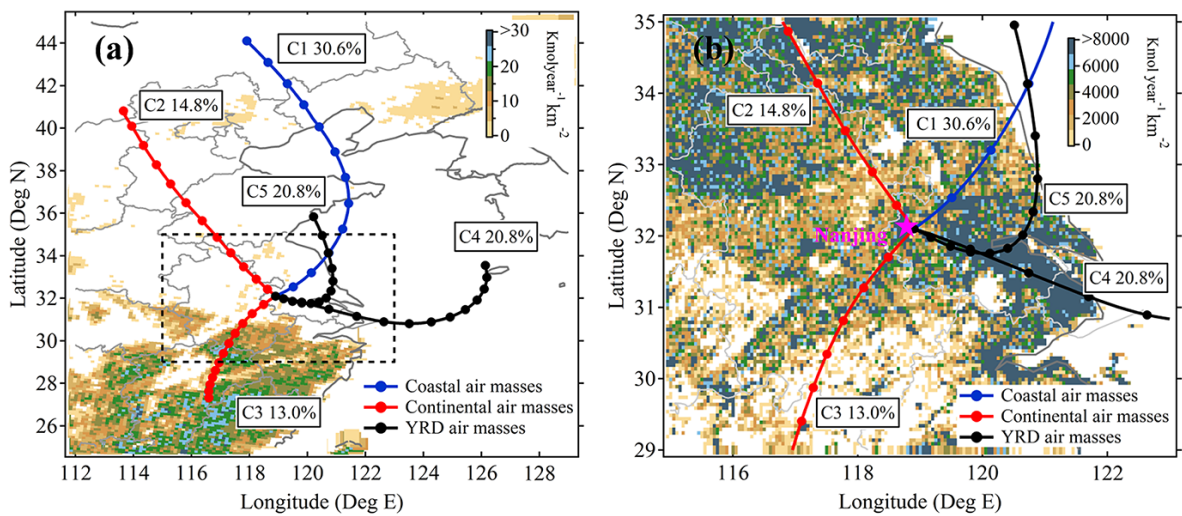

Figure 6. Mean air mass backward trajectories of five clusters showing on maps of emission inventory of (a) monoterpenes in eastern China and (b) anthropogenic VOCs in the YRD. Note: points of trajectories represent the 6-hourly location. The percentages of each cluster are tabulated in the map. The monoterpene data were calculated by MEGAN (Model of Emissions of Gases and Aerosols from Nature) with MM5 (the Fifth-Generation Mesoscale Model) providing meteorological data and the anthropogenic VOC data were accessed from the MEIC (Multi-resolution Emission Inventory for China) database (http://www.meicmodel.org/).

soon bringing regional pollution from the North China Plain $(\mathrm{C} 2, \mathrm{C} 1$ and $\mathrm{C} 5)$ and the summer monsoon bringing the YRD regional pollution (C4) or biogenic emissions from the south of China to the site (C3). Being located in the most western part of the YRD, SORPES is a unique site to investigate the impact of different regional air masses.

The average behavior of the particles number size distributions and diurnal variations of NCs in the three modes in the five air mass clusters are shown in Fig. 7. The coastal air masses (C1) had the lowest accumulation-mode particle loading during the whole day (Fig. 7d). The continental air masses (C2 and C3) had highest levels of nucleationmode particles (Fig. 7b), probably associated with the dry and sunny weather. Since C3 air masses occurred mostly in summer and traveled over regions abundant in BVOC emissions, these air masses preferred NPF and resulted in the highest concentrations of nucleation-mode and Aitken-mode particles (Fig. 7b, c). The YRD air masses (C4 and C5), passing through the YRD city clusters, brought the highest accumulation-mode particle loadings (Fig. 7d) and lowered concentrations of nucleation-mode particles (Fig. 7b) due to the high coagulation/condensation sinks. C5 air masses, with more local air and less influences of marine air, displayed larger concentrations of accumulation-mode particles and lower concentrations of Aitken-mode particles (Fig. 7c, d).

\subsection{New particle formation (NPF)}

\subsubsection{Population statistic about NPF}

The sampling days during the 2 years of measurements were classified into NPF-event days, non-event days and undefined days with the criterion of whether a nucleation burst occurred or not. By following the method used by Dal Maso et al. (2005) and Kulmala et al. (2012), the event days are further classified into Class I when the formation and growth rate can be calculated with confidence, and Class II when the formation and growth rate cannot be calculated or done in accurate ways.

The numbers of the four types of sampling days are given in Table 2 and the percentages of them in each month are shown in Fig. 8a. Due to instrument maintenance, data from 

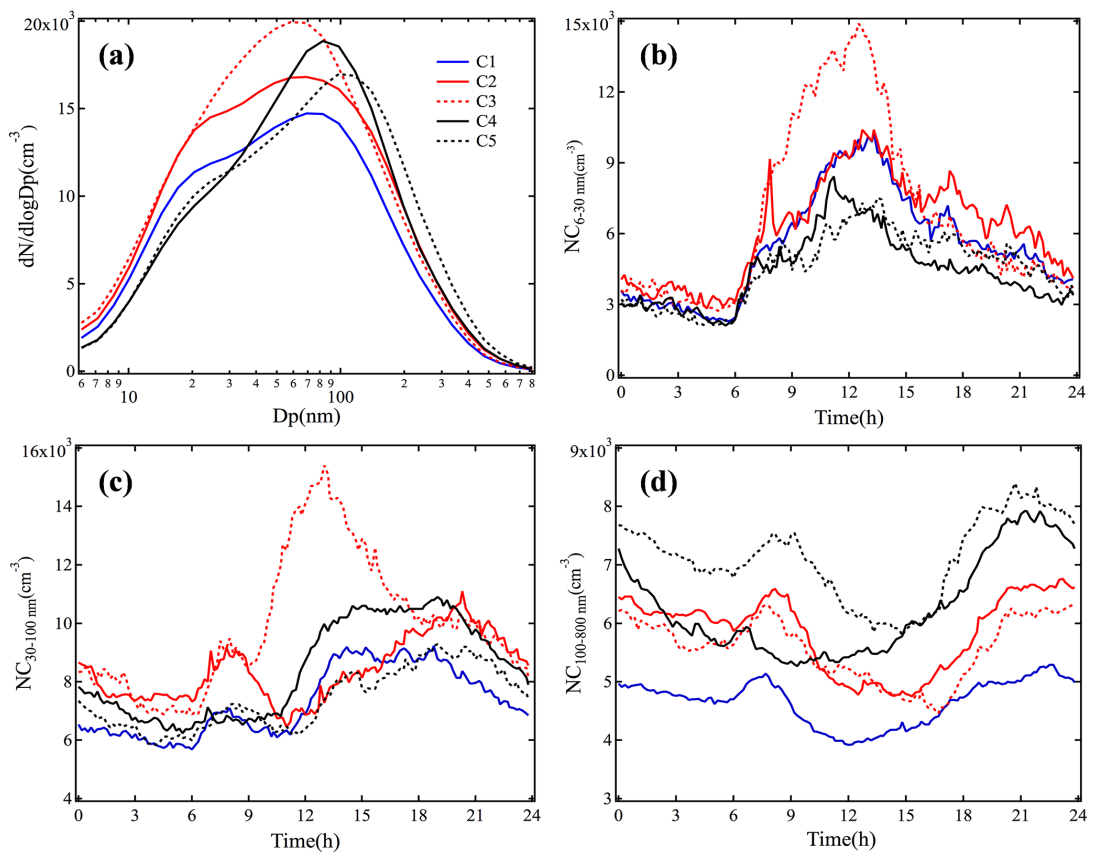

Figure 7. (a) Particle number size distributions of five clusters (C1, C2, C3, C4 and C5 air masses, respectively); diurnal variations of particle number concentration of five clusters in (b) nucleation $(6-30 \mathrm{~nm})$, (c) Aitken (30-100 nm) and (d) accumulation modes (100-800 nm).

Table 2. Statistics of NPF events, $J_{6}$ and $\mathrm{GR}_{6-30 \mathrm{~nm}}$ at the SORPES station during the 2-year measurement period (SD: standard deviation).

\begin{tabular}{llllll}
\hline & & Spring & Summer & Autumn & Winter \\
\hline Event classification & Class I & 52 & 44 & 64 & 10 \\
& Class II & 42 & 29 & 24 & 5 \\
& Non-event & 75 & 60 & 89 & 115 \\
& Undefined & 3 & 3 & 1 & 4 \\
$J_{6}\left(\mathrm{~cm}^{-3} \mathrm{~s}^{-1}\right)$ & Mean \pm SD & $3.6 \pm 2.4$ & $2.1 \pm 1.4$ & $2.1 \pm 1.9$ & $1.8 \pm 1.6$ \\
$\mathrm{GR}_{6-30 \mathrm{~nm}}\left(\mathrm{~nm} \mathrm{~h}^{-1}\right)$ & Mean \pm SD & $10.0 \pm 3.4$ & $12.8 \pm 4.4$ & $8.9 \pm 2.9$ & $9.5 \pm 3.3$ \\
\hline
\end{tabular}

111 days of the 2-year period were unavailable for the event's classification. Only few of the days at SORPES were considered as undefined days (11 days), for which it was hard to determine whether a NPF event occurred or not. Overall, NPFevent days (including Class I and Class II days) accounted for $44 \%$ of the sampling days. This frequency is a bit higher than observed in the other two long-term measurements in China (urban Beijing 40\%, SDZ 37\%). In spring, summer and autumn, NPF events took place in about half of the sampling days $(55,54$ and $49 \%$, respectively), which is more frequent than at other measurement sites in China, including Taicang (44\%), Hong Kong (34\%) and Xinken (26\%) (Gao et al., 2009; Guo et al., 2012; Liu et al., 2008). A higher frequency of NPF events in the warm season is similar to what has been observed in most other sites all over the world and is mainly because of higher radiation and stronger biogenic activity during that time of the year (Manninen et al., 2010). In contrast, in winter only $15 \mathrm{NPF}$-event days during the 2-year measurement period were identified. This frequency is sim- ilar to another work in Shanghai (Du et al., 2012) but quite different from that in Beijing where winter is the second season favorable to NPF (Wu et al., 2007; Shen et al., 2011). One explanation for this could be that there are more "clean" days in winter in Beijing because of frequent cold fronts (Wehner et al., 2008). In June, continuous rainy days ("plum rain" in China) with low radiation also inhibit the NPF events. There was a great difference in the frequency of NPF events in summer between the 2 years: $39 \%$ in 2012 and $66 \%$ in 2013 (Fig. 8a).

Figure $8 \mathrm{~b}$ gives the variability of start and end times of the Class I event days. Since the cutoff diameter of the DMPS was $6 \mathrm{~nm}$, the start and end times were defined here as the times when the 6-7 nm particles started to increase and decrease back to the background level (i.e., $\sim 50 \mathrm{~cm}^{-3}$ ). Generally, the start time was somewhere between the sunrise and midday, and no evident nocturnal events were identified. The seasonal variation of the start time followed that of sunrise, which is similar to what has been reported elsewhere around 

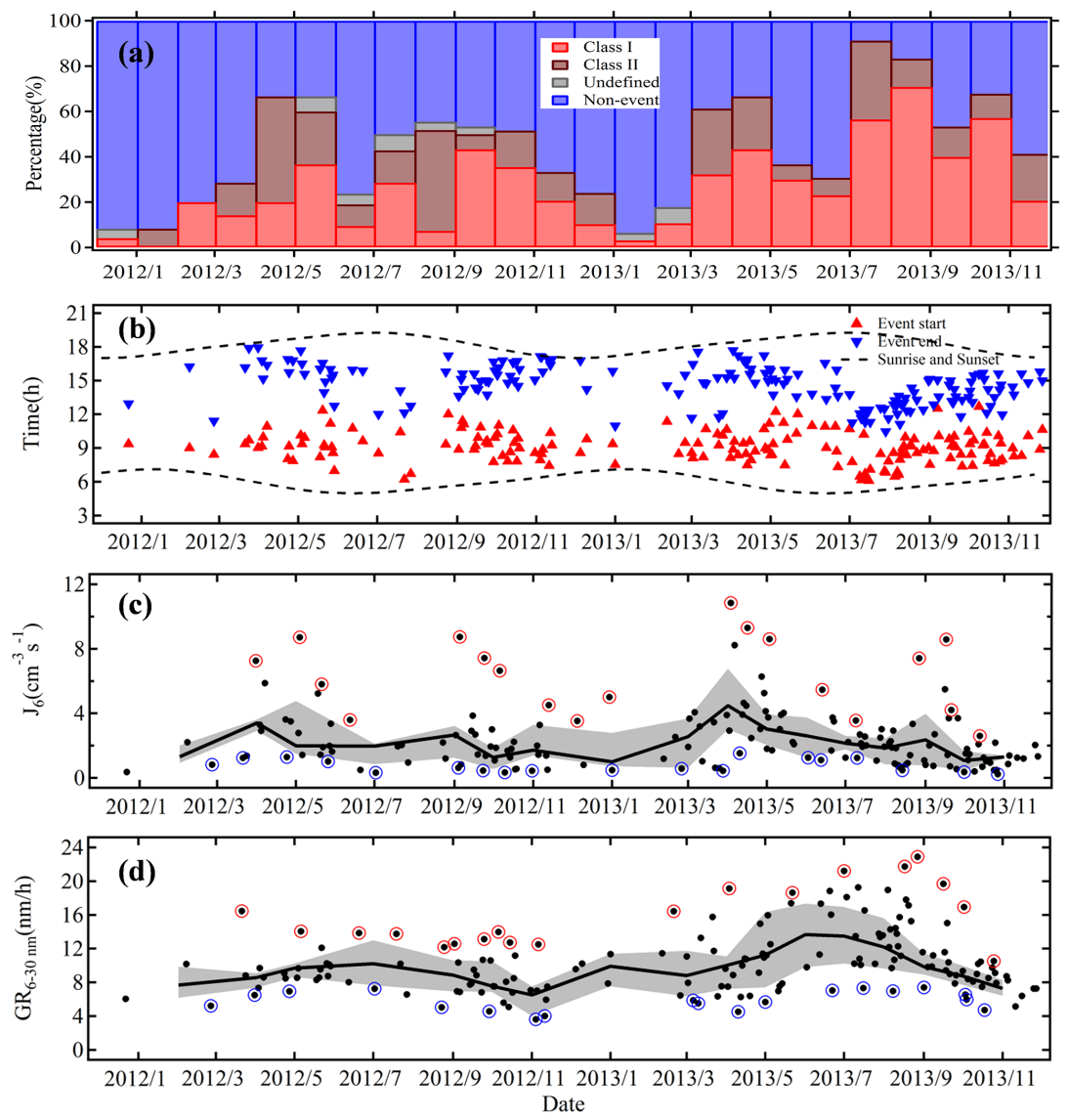

Figure 8. Monthly time series of (a) the fraction of Class I, Class II NPF events, undefined and non-event days, (b) start time and end time of Class I event days, (c and d) $J_{6}$ and growth rate during Class I event days. Note: Dashed lines in Fig. 8b represent the sunrise and sunset time. Bold solid lines in Fig. 8c and d are the median values and shaded areas represent the 25 th or 75 th percentiles. Red circles and blue circles in Fig. 8c and d are the days that selected for further investigation in Sect. 3.2.3.

the world (e.g., Woo et al., 2001; Boy and Kulmala et al., 2002; Kulmala et al., 2004; Hamed et al., 2007; Wu et al., 2007). However, on some days the start time was just $1 \mathrm{~h}$ after the sunrise. Most of such events took place in summer and were associated with marine air masses that had been transported over the polluted area in the YRD. This topic will be studied further in our future work.

The formation rate of $6 \mathrm{~nm}$ particles $\left(J_{6}\right)$ and growth rate of $6-30 \mathrm{~nm}$ particles $\left(\mathrm{GR}_{6-30 \mathrm{~nm}}\right)$ during the Class I event days are illustrated in Fig. 8c and d. The statistical results are given in Table 2. The formation rates were highest in spring with the value of $3.6 \pm 2.4 \mathrm{~cm}^{-3} \mathrm{~s}^{-1}$, followed by summer $\left(2.1 \pm 1.4 \mathrm{~cm}^{-3} \mathrm{~s}^{-1}\right)$ and autumn $\left(2.1 \pm 1.9 \mathrm{~cm}^{-3} \mathrm{~s}^{-1}\right)$, whereas the lowest formation rates were observed in winter $\left(1.8 \pm 1.6 \mathrm{~cm}^{-3} \mathrm{~s}^{-1}\right)$. The maximum formation rate was $10.9 \mathrm{~cm}^{-3} \mathrm{~s}^{-1}$ on 3 April 2013. The observed formation rates in Nanjing are comparable to other measurements in China, e.g., $3.3-81.4 \mathrm{~cm}^{-3} \mathrm{~s}^{-1}$ in Beijing (for $J_{3}$ ), 0.7-72.7 $\mathrm{cm}^{-3} \mathrm{~s}^{-1}$ with mean value of $8 \mathrm{~cm}^{-3} \mathrm{~s}^{-1}$ at SDZ (Shangdianzi) (for $J_{3}$ ) $3.4 \mathrm{~cm}^{-3} \mathrm{~s}^{-1}$ (3 October-
5 November 2004) in the PRD (Pearl River Delta) (for $J_{3}$ ), $3.8 \mathrm{~cm}^{-3} \mathrm{~s}^{-1}$ (25 October-29 November 2010) in Hong Kong (for $J_{5.5}$ on Class I days), and about $2.2 \mathrm{~cm}^{-3} \mathrm{~s}^{-1}$ (5 May-2 June 2005) in Shanghai (for $J_{10}$ ) (Wu et al., 2007; Shen et al., 2011; Liu et al., 2008; Guo et al., 2012; Gao et al., 2009). Concerning the nuclei growth rates, the highest values of $12.8 \pm 4.4 \mathrm{~nm} \mathrm{~h}^{-1}$ were observed in summer, followed by spring $\left(10.0 \pm 3.4 \mathrm{~nm} \mathrm{~h}^{-1}\right)$, winter $\left(9.5 \pm 3.3 \mathrm{~nm} \mathrm{~h}^{-1}\right)$ and autumn $\left(8.9 \pm 2.9 \mathrm{~nm} \mathrm{~h}^{-1}\right)$. The maximum growth rate was $22.9 \mathrm{~nm} \mathrm{~h}^{-1}$, observed on 29 August 2013. The values of growth rates presented in this study for Nanjing are slightly higher than those reported for the other two long-term measurements in China, i.e., $0.1-11.2 \mathrm{~nm} \mathrm{~h}^{-1}$ in Beijing and 0.3$14.5 \mathrm{~nm} \mathrm{~h}^{-1}$ with mean value of $4.3 \mathrm{~nm} \mathrm{~h}^{-1}$ at SDZ (Wu et al., 2007; Shen et al., 2011).

\subsubsection{Conditions favoring NPF}

In Fig. 9, we compare the NPF-related parameters between the event (Class I and Class II) and non-event days in different seasons. As shown in Fig. 9a and b, higher temperatures 

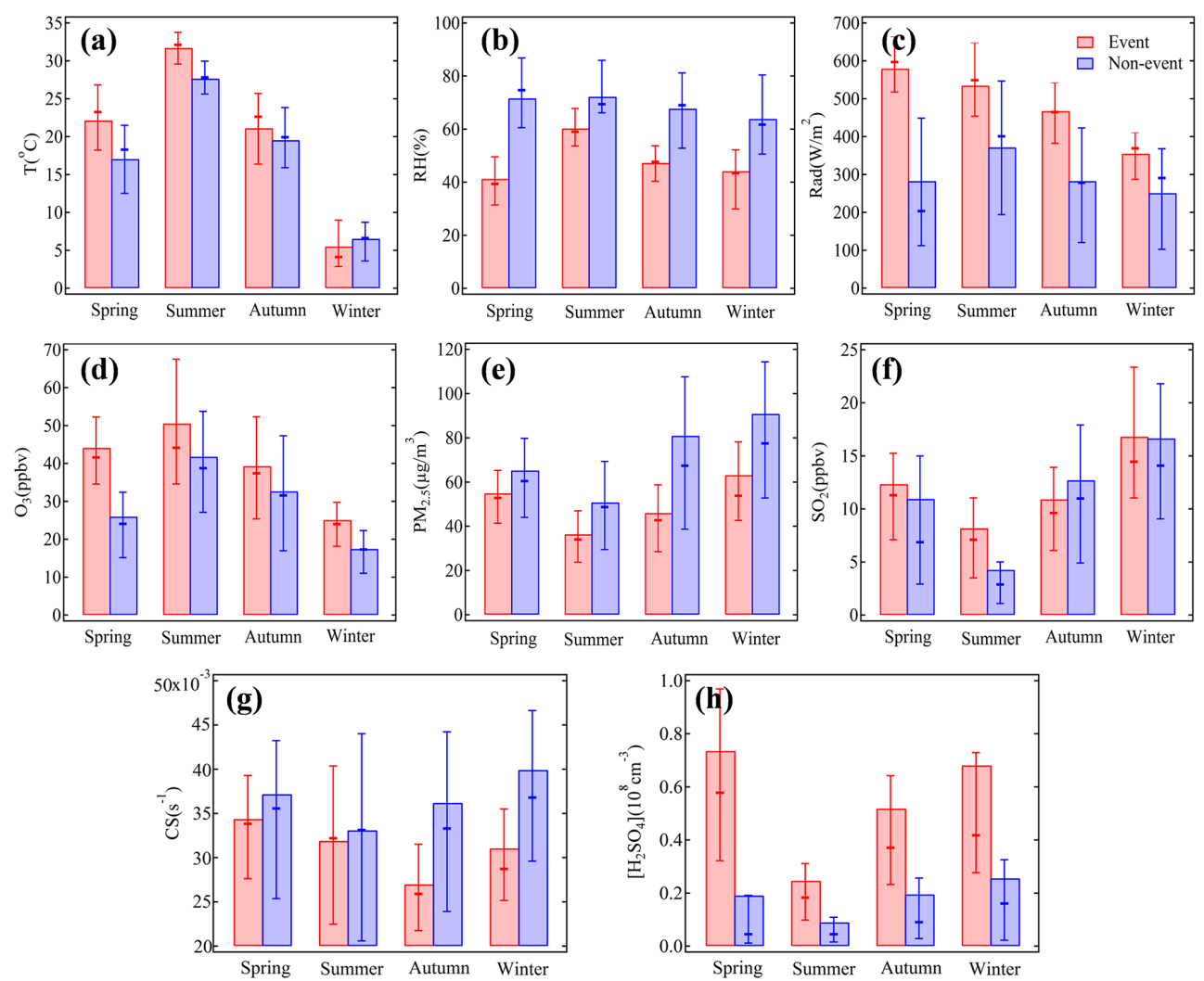

Figure 9. (a-c) Meteorological variables, (d-f) gaseous pollutants, (g) condensation sink and (h) $\mathrm{H}_{2} \mathrm{SO}_{4}$ proxy during event (red) and nonevent (blue) days in different seasons. Note: bars are the mean value. The bold sticks and whiskers indicate the median values and the 25th and 75 th percentiles, respectively.

and lower RH favored the NPF events. Having a higher temperature on event days is similar to observations made in Germany and Italy (Birmili and Wiedensohler, 2000; Birmili et al., 2003; Hamed et al., 2007) but different from observations made in Finland or in the tropopause region (Boy and Kulmala, 2002; Hamed et al., 2007; Young et al., 2007). A lower $\mathrm{RH}$ on event days is similar to what has been observed in most boundary layer stations (Boy and Kulmala, 2002; Birmili et al., 2003; Hamed et al., 2007; Guo et al., 2012). In general, a low RH is related to sunny days with strong radiation, which favor the formation of $\mathrm{OH}$ (Hamed et al., 2007). In addition, a low RH will decrease the condensation sink by slowing the hygroscopic growth (Hamed et al., 2011).

Radiation and $\mathrm{O}_{3}$ concentrations were higher on event days than on non-event days (Fig. 9c, d), indicating that the observed NPF events in the YRD were typically photochemically influenced. In line with most boundary layer stations (Manninen et al., 2010), lower $\mathrm{PM}_{2.5}$ concentrations and CS favored the occurrence of NPF events (Fig. 9e, g). On average, higher $\mathrm{SO}_{2}$ concentrations were observed on event days in spring and summer, while the events in autumn and winter favored lower $\mathrm{SO}_{2}$ concentrations (Fig. 9f). This result was in accordance with our previous study conducted in the
Table 3. Statistics of NPF events in different air mass clusters.

\begin{tabular}{lllll}
\hline & Class I & Class II & Non-event & Undefined \\
\hline C1 & 52 & 25 & 82 & 3 \\
C2 & 25 & 19 & 48 & 0 \\
C3 & 32 & 22 & 12 & 0 \\
C4 & 33 & 13 & 69 & 4 \\
C5 & 20 & 11 & 72 & 3 \\
\hline
\end{tabular}

wintertime, which suggested that NPF occurs preferably under conditions of lower $\mathrm{SO}_{2}$ concentrations (Herrmann et al., 2014). In autumn and winter, the $\mathrm{SO}_{2}$ peaks were always accompanied with a high $\mathrm{PM}_{2.5}$ concentration in the YRD. Therefore, the observed lower $\mathrm{SO}_{2}$ concentrations on event days in autumn and winter are understandable as the preexisting particles play a more important role. The proxy of $\mathrm{H}_{2} \mathrm{SO}_{4}$ was significantly higher on event days than on nonevent days, suggesting the sulfuric acid was the main driver of NPF events at SORPES.

The statistics of the NPF events in different air mass clusters are given in Table 3. The events influenced by two or more air mass groups, $17 \%$ of the sampling days, were 

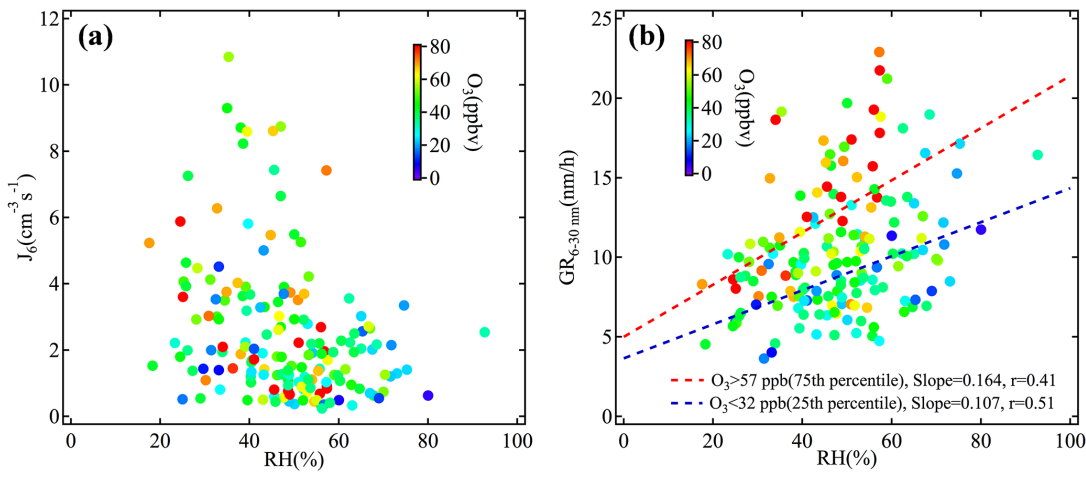

Figure 10. Scatter plot (a) between $J_{6}$ and $\mathrm{RH}$ and (b) between $\mathrm{GR}_{6-30 \mathrm{~nm}}$ and $\mathrm{RH}$, color coded with $\mathrm{O}_{3}$ concentration. Note: linear fits for the data when the $\mathrm{O}_{3}$ concentration is higher than $57 \mathrm{ppbv}$ (the 75 th percentile) or lower than 32 ppbv (the 25th percentile) are shown in Fig. 10b, respectively.

Table 4. Correlation coefficients of $J_{6}$ and $\mathrm{GR}_{6-30 \mathrm{~nm}}$ with the main meteorological parameters and air pollutants.

\begin{tabular}{lrrrrrrrr}
\hline & $\begin{array}{r}\text { Temp. } \\
\left({ }^{\circ} \mathrm{C}\right)\end{array}$ & $\begin{array}{r}\mathrm{RH} \\
(\%)\end{array}$ & $\begin{array}{r}\text { Radiation } \\
\left(\mathrm{W} \mathrm{m}^{-2}\right)\end{array}$ & $\begin{array}{r}\mathrm{O}_{3} \\
(\mathrm{ppbv})\end{array}$ & $\begin{array}{r}\mathrm{PM}_{2.5} \\
\left(\mu \mathrm{g} \mathrm{m}^{-3}\right)\end{array}$ & $\begin{array}{r}\mathrm{SO}_{2} \\
(\mathrm{ppbv})\end{array}$ & $\begin{array}{r}\mathrm{NO}_{x} \\
(\mathrm{ppbv})\end{array}$ & $\begin{array}{r}\mathrm{CS} \\
\left(10^{-2} \mathrm{~s}^{-1}\right)\end{array}$ \\
\hline$J_{6}\left(\mathrm{~cm}^{-3} \mathrm{~s}^{-1}\right)$ & 0.10 & $-0.31^{*}$ & $0.32^{*}$ & $0.17^{*}$ & 0.01 & 0.11 & -0.01 & 0.06 \\
$\mathrm{GR}_{6-30 \mathrm{~nm}}\left(\mathrm{~nm} \mathrm{~h}^{-1}\right)$ & $0.36^{*}$ & $0.27^{*}$ & $0.27^{*}$ & $0.38^{*}$ & 0.07 & 0.06 & -0.14 & $0.38^{*}$ \\
\hline
\end{tabular}

* The correlation coefficient passes the statistical significant test $(p<0.05)$.

not included in this statistic. Air masses in $\mathrm{C} 3$ revealed the most frequent NPF (54 event days and 12 non-event days). As illustrated in Sect. 3.1.4, C3 air masses took place usually in summer and brought large amounts of BVOCs (e.g., monoterpenes) from southern China (Fig. 6a). BVOC emissions have previously been observed to contribute to the formation and growth of new particles (Birmili et al., 2003; Tunved et al., 2006; Fu and Kawamura, 2011; Kamens et al., 2011). Air masses in C4 and C5, which passed through a polluted YRD area with lots of pre-existing particles, generally had less NPF events, further indicating that the polluted YRD plume would suppress the formation of new particles. In winter, when solar radiation is low, no NPF events occurred in the YRD area masses (Herrmann et al., 2014).

\subsubsection{Factors influencing particle formation and growth rates}

To investigate the factors that influence the formation rate and growth rate, the correlation coefficients of $J_{6}$ and $\mathrm{GR}_{6-30 \mathrm{~nm}}$ with meteorological quantities and gaseous pollutants were calculated (Table 4). The correlation coefficients that passed the statistical significance test $(p<0.05)$ were highlighted by asterisk in Table 4 . The particle formation rate $\left(J_{6}\right)$ was negatively correlated with $\mathrm{RH}$ and positively correlated with both radiation and $\mathrm{O}_{3}$. No significant correlation between $J_{6}$ and $\mathrm{SO}_{2}$ was seen at SORPES. The particle growth rate was positively correlated with temperature, $\mathrm{RH}$, radiation, $\mathrm{O}_{3}$ and $\mathrm{CS}(p<0.05)$. It is worth noting here that while lower values of $\mathrm{RH}$ and $\mathrm{CS}$ appeared to favor the occurrence of a NPF event, higher values of these two quantities clearly favored the particle growth. This suggests that the new formation and growth are influenced, at least to some extent, by different processes and vapors (Yli-Juuti et al., 2011; Rose et al., 2015). The scatter plots of $J_{6}-\mathrm{RH}$ and $\mathrm{GR}_{6-30 \mathrm{~nm}}-\mathrm{RH}$ color coded with $\mathrm{O}_{3}$ mixing ratios are shown in Fig. 10. The negative correlation between $J_{6}$ and $\mathrm{RH}$ did not depend on the $\mathrm{O}_{3}$ concentration (Fig. 10a), whereas for $\mathrm{GR}_{6-30 \mathrm{~nm}}$ an obvious difference in the $\mathrm{GR}_{6-30 \mathrm{~nm}}-\mathrm{RH}$ slope could be identified for different levels of the $\mathrm{O}_{3}$ mixing ratio (Fig. 10b). Here the good GR-RH relationship may also be influenced by factors other than the $\mathrm{O}_{3}$ mixing ratio, such as the transport compounds acting as precursors for the vapors responsible for the particle growth. Because of the influence of the summer monsoon, air masses from the southeast and southwest directions are generally much humid than those from the north (Ding et al., 2013a). These southerly air masses could also be accompanied with a high concentration of BVOCs or anthropogenic VOCs and their oxidants. Ding et al. (2013a) found that air masses from the YRD city clusters were always associated with high concentrations of $\mathrm{O}_{3}$, which should also contain high concentrations of anthropogenic VOCs.

In order to study further the event with a high or low value of $J_{6} / \mathrm{GR}_{6-30 \mathrm{~nm}}$, we conducted Lagrangian dispersion modeling for the selected days marked in Fig. 8c and d by using the method developed by Ding et al. (2013c), based on the 

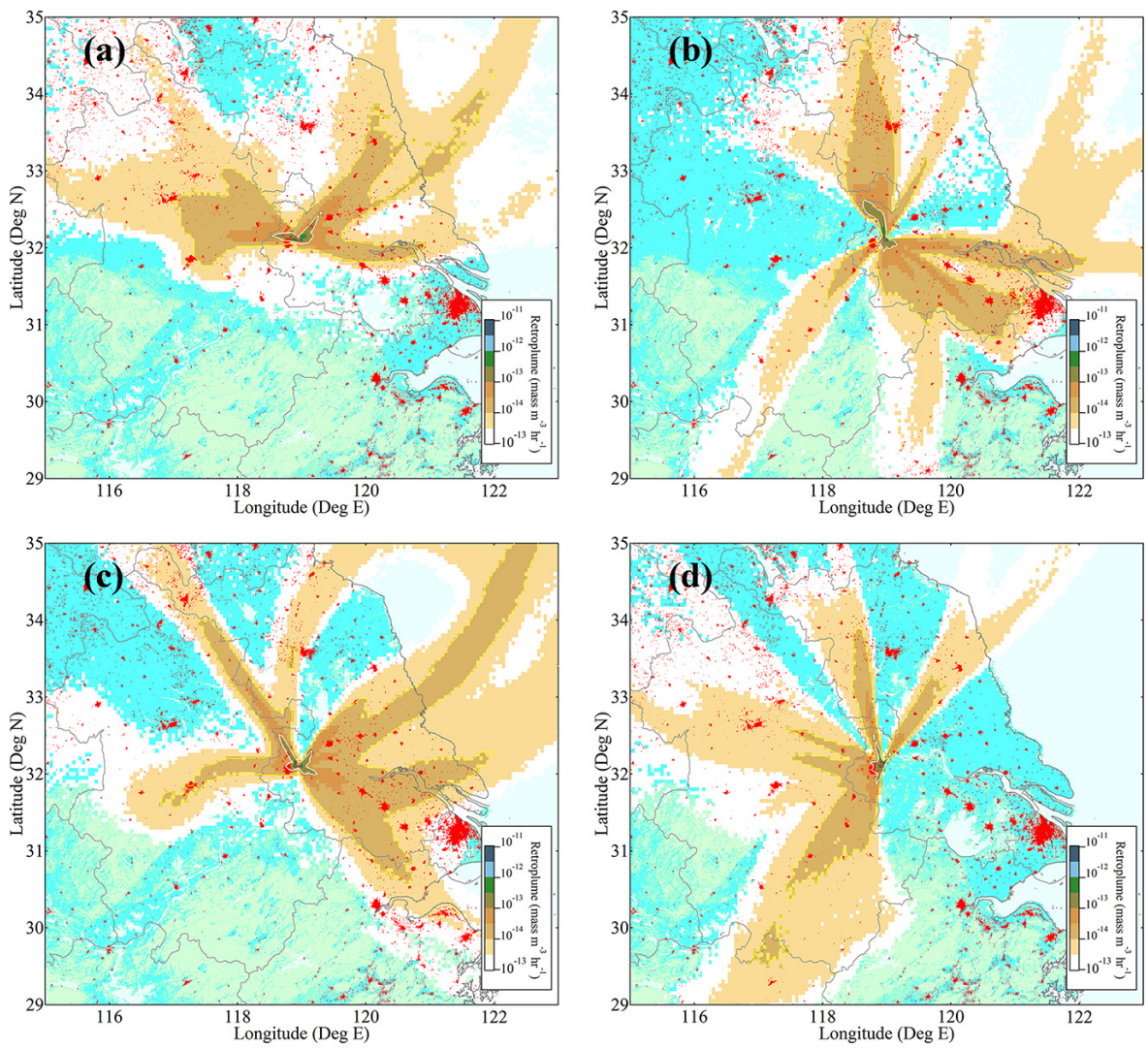

Figure 11. The averaged retroplumes (i.e., $100 \mathrm{~m}$ footprint) of the selected events: (a) high $J_{6}$, (b) low $J_{6}$, (c) high GR, (d) low GR days (the dates are marked in Fig. $8 \mathrm{c}$ and d.). Note: the red areas in the maps show the locations and sizes of the cities.

HYSPLIT model, to study the influence of air masses. Figure 11 gives the footprint, i.e., a retroplume at an altitude of $100 \mathrm{~m}$, of the selected high and low $J_{6} / \mathrm{GR}_{6-30 \mathrm{~nm}}$ days. Air masses had an obvious influence on the formation rate and growth rate. Most low $J_{6}$ days and high GR days occurred in the air masses passing over the polluted YRD area, while all the high $J_{6}$ days and low GR days appeared in air masses that did not go through the YRD area. This further suggests the differences in the particle formation and growth processes could partly explain the positive correlation between the GR and RH. In addition to the high RH in YRD air masses, the high anthropogenic VOC concentration may play a more important role in enhancing the particle growth. Our finding that the polluted YRD plume induces a high GR is consistent with the studies reporting relatively high particle growth rates under urban conditions (Kulmala and Kerminen, 2008; Peng et al., 2014).

\subsection{Causes on the high frequency of NPF in August 2013}

As shown in Fig. 8, a higher frequency of NPF events occurred in July and August of 2013 compared with the same months in 2012. In August of 2013, the frequency of Class I
NPF events was highest during the 2-year measurement period, with 17 Class I events observed among the 24 analyzed days. Figure 12 shows the time series of particle number size distribution, $\mathrm{O}_{3}$ and $\mathrm{PM}_{2.5}$ concentrations, and radiation. The daily average $\mathrm{O}_{3}$ concentration gradually increased in early August with an hourly maximum value of up to $165 \mathrm{ppbv}$ on 12 August 2013. Accompanied with this $\mathrm{O}_{3}$ episode, the geometric mean diameter (GMD) of submicron particles and $\mathrm{PM}_{2.5}$ concentration also increased (Fig. 12a, b). Interestingly, there were continuously multi-day NPF events in the first half of this month, even during 11-13 August when $\mathrm{PM}_{2.5}$ reached 70-80 $\mu \mathrm{g} \mathrm{m}^{-3}$. During 17-24 August, there were also notable NPF events. Contrary to this, few NPF took place in August 2012.

Examination of the average geopotential height and wind vectors at the $925 \mathrm{hPa}$ level during the two Augusts suggests that in 2013 the subtropical (Pacific) high moved more to the west than that in 2012, causing a positive anomaly (high pressure) and anticyclone over southeastern China (Fig. 13). As a result, the YRD experienced a continuous heat wave with humid and hot air transported from the south and southwest.

In order to further understand the air masses' history during the events in 2013, Fig. 14 gives the averaged "footprint" (i.e., $100 \mathrm{~m}$ retroplume) for the episode period. The 


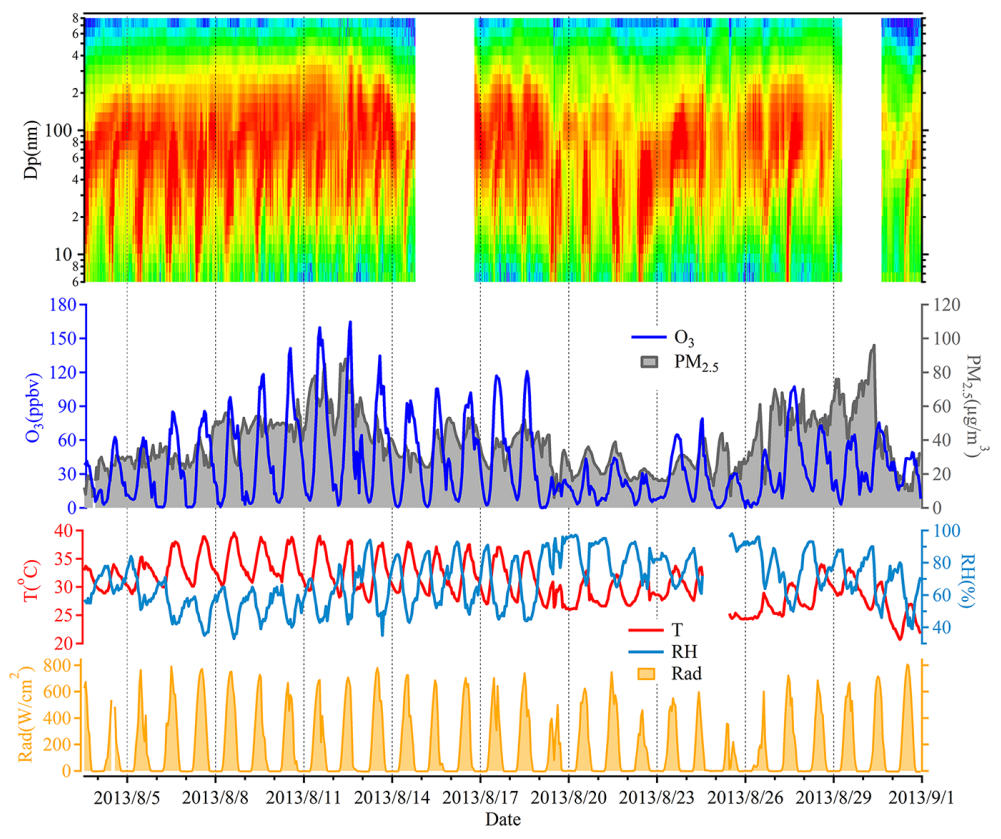

Figure 12. Time series of (a) particle number size distribution, (b) $\mathrm{O}_{3}$ and $\mathrm{PM}_{2.5}$ concentrations, (c) temperature and $\mathrm{RH}$, and (d) intensity of radiation measured at the SORPES site in August 2013.
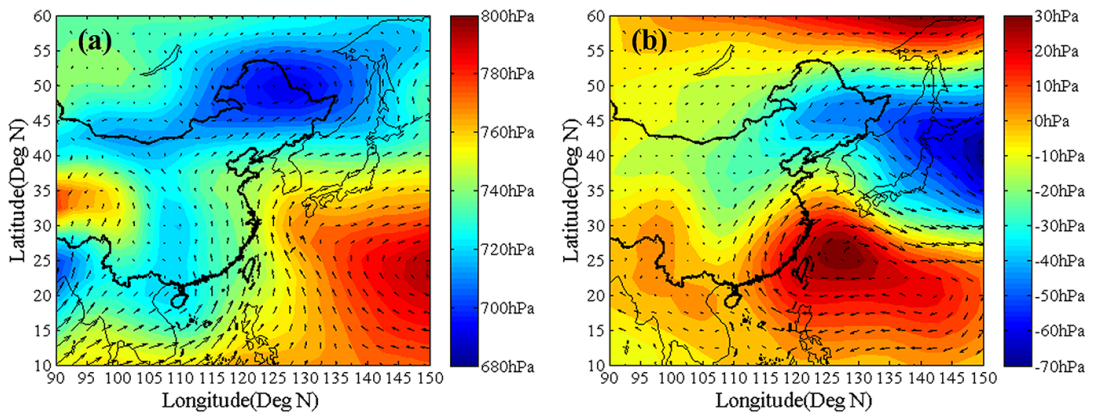

Figure 13. (a) Average geopotential height and wind vectors at the $925 \mathrm{hPa}$ level during August 2013. (b) Differences in geopotential height and wind vectors between August 2013 and August 2012 at the $925 \mathrm{hPa}$ level.

air masses can be divided into three time periods. During 611 August, the air masses came from the southwest with a high value of BVOCs and they also passed through the downtown of Nanjing. During this period, $\mathrm{O}_{3}$ was produced and accumulated with enough precursors and strong solar radiation. High $\mathrm{O}_{3}$ concentrations also caused a strong atmospheric oxidation capacity, which caused an increase in the GMD of submicron particles together with an increase in the $\mathrm{PM}_{2.5}$ mass concentration. On 11 August, the air masses' transport pathway was changed, with air masses coming mainly from the southeast and the YRD city cluster, which is the most polluted area with high value of anthropogenic VOCs and other pollution gases. Therefore, the $\mathrm{O}_{3}$ concentration continued to increase until 12 August and then maintained a high level until 19 August. A common character of the air masses during both of these two periods was that the air was transported over regions with high biogenic and anthropogenic emissions (See Figs. 6a, b and 14). During 1922 August, the air masses were mainly from the northeast and had a high humidity that caused cloudy days with low radiation and high wet deposition. The $\mathrm{O}_{3}$ concentration, GMD of submicron particles and $\mathrm{PM}_{2.5}$ mass concentration therefore sharply decreased on 19 August.

Despite the high levels of GMD, $\mathrm{PM}_{2.5}$ and CS (which is not shown in Fig. 12), Class I NPF events occurred every day during the whole $\mathrm{O}_{3}$ episode (from 4 to 19 August 2013). As the GMD and $\mathrm{PM}_{2.5}$ increased, the particle formation rates became lower. This means that the high values of GMD and $\mathrm{PM}_{2.5}$ suppressed new particle formation but could not stop the occurrence of NPF event altogether under such an atmospheric condition of a high oxidization capacity. Because of lower pre-existing particle loading after 19 August, new 


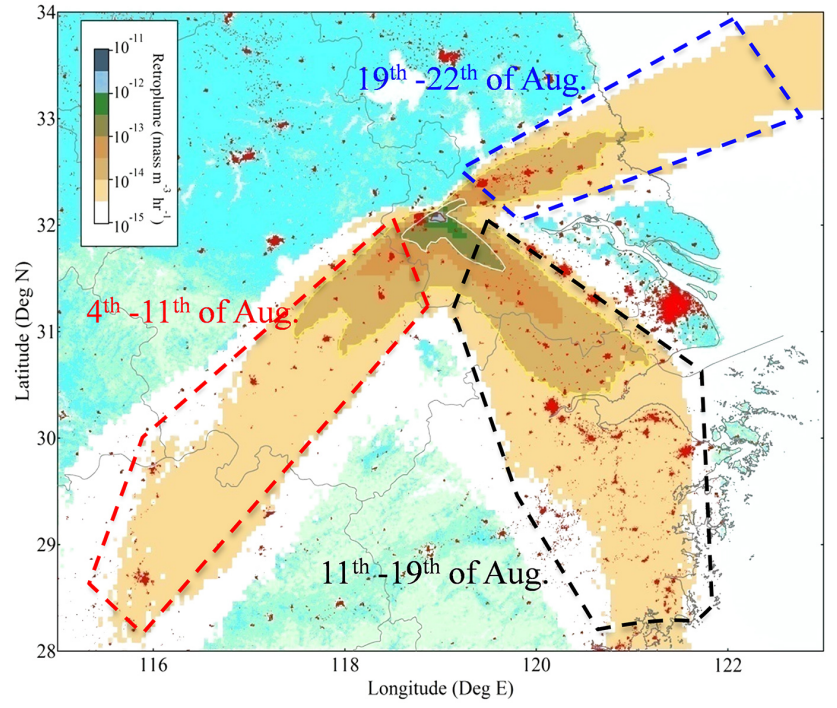

Figure 14. Retroplumes from 4 to 22 August 2013 identified with three main periods. Note: red points denote the urban area.

particle formation continued, although the radiation intensity and atmospheric ozone oxidation capacity were lower. Another obvious character for August 2013 was that, during the whole month, the particle growth rate had a relatively high correlation with RH $(r=0.54)$, supporting the positive correlation between GR and RH illustrated above (Fig. 15).

Here the year-to-year difference in aerosol size distributions and NPF characteristics suggests that large-scale circulations together with meteorological factors had a strong impact on the aerosol number concentration. Extreme meteorological conditions are able to reshape the seasonal profile of the aerosol number concentration and NPF, which means that measurements in a specific year cannot gain a full picture of seasonal profiles. Given the fact that there are only a limited number of measurements covering more than 1 year, especially in China, this work highlights the importance of long-term continuous measurement.

\section{Summary}

This study reports a 2-year measurement (from December 2011 to November 2013) period of submicron particles $(6-800 \mathrm{~nm})$ at the SORPES station located in suburban Nanjing in the western part of the YRD, eastern China, with the aims of characterizing the temporal variation of the particle number concentration and size distribution and understanding the new particle formation occurring in such a polluted monsoon area.

The average total number concentrations was $19200 \pm 9200$ (mean \pm standard deviation) $\mathrm{cm}^{-3}$, with $5300 \pm 5500 \mathrm{~cm}^{-3}$ in the nucleation mode $(6-30 \mathrm{~nm})$, $8000 \pm 4400 \mathrm{~cm}^{-3}$ in the Aitken mode $(30-100 \mathrm{~nm})$ and

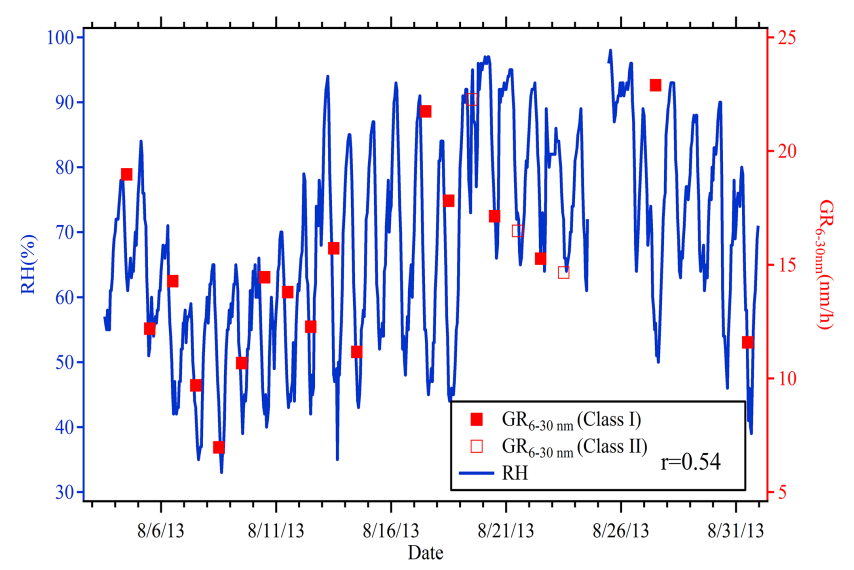

Figure 15. Time series of $\mathrm{RH}$ and the $\mathrm{GR}_{6-30 \mathrm{~nm}}$ of NPF days (Class I and Class II) in August 2013.

$5800 \pm 3200 \mathrm{~cm}^{-3}$ in the accumulation mode $(100-800 \mathrm{~nm})$. Seasonal variations of NC and size distribution were influenced by the Asian monsoon, anthropogenic activities and the atmospheric oxidation capacity. The diurnal pattern of the particle number size distribution in winter showed peaks at the normal rush hours, suggesting the emissions of vehicles as the direct source. Air mass long-range transportation played a clear role in influencing the particle number concentration: coastal air masses had the lowest concentrations of accumulation-mode particles but relatively high concentrations of nucleation-mode particles, continental air masses had the highest concentrations of nucleation-mode particles with frequent new particle formation, and YRD air masses had the highest concentrations of accumulationmode particles and lowest concentration of nucleation-mode particles because of the elevated coagulation/condensation sinks.

NPF events were observed on $44 \%$ of the analyzed days with the highest frequency in spring, followed by summer and autumn but only 15 event days in winter. The average formation rates of $6 \mathrm{~nm}$ particles were $3.6 \pm 2.4,2.1 \pm 1.4$, $2.1 \pm 1.9$ and $1.8 \pm 1.6 \mathrm{~cm}^{-3} \mathrm{~s}^{-1}$ in spring, summer, autumn and winter, respectively, and the corresponding particle growth rates were $10.0 \pm 3.4,12.8 \pm 4.4,8.9 \pm 2.9$ and $9.5 \pm 3.3 \mathrm{~nm} \mathrm{~h}^{-1}$. A higher temperature, radiation intensity and $\mathrm{O}_{3}$ concentration together with a lower $\mathrm{RH}, \mathrm{PM}_{2.5}$ and CS seemed to favor the occurrence of new particle formation events. Sulfuric acid appeared to play a key role in NPF events at SORPES. Trajectory analysis suggested that BVOC chemistry contributed to the new particle formation and growth. The particle formation rate was negatively correlated with $\mathrm{RH}$ and positively correlated with radiation and $\mathrm{O}_{3}$ while particle growth rate was positively correlated with temperature, $\mathrm{RH}$, radiation, $\mathrm{O}_{3}$ and $\mathrm{CS}$. Both particle formation and growth rate depended on the air mass origin, with low $J_{6}$ and high GR typical for polluted YRD air masses and high $J_{6}$ and low GR for clean air masses. 
The observed frequency of NPF events and particle growth rate in summer showed a strong year-to-year variation under the influence of different large-scale circulations, such as the intensity and location of a subtropical high pressure system. Long-range transport, meteorological parameters and photochemical pollutants promoted the atmospheric new particle formation and growth in the summer of 2013 compared with the previous year. To quantitatively understand the processes controlling the aerosol number concentration and size distribution, or to predict their behavior, additional modeling work on NPF that relies on long-term observations should be conducted in future. 


\section{Appendix A: Performance of the flow-switching DMPS}

The flow-switching DMPS has two flow modes to measure the particles in two size ranges, $6-100$ and $100-800 \mathrm{~nm}$. To assimilate data in the two flow modes, in this study the number concentrations of particles in the size range from 100 to $800 \mathrm{~nm}$ were multiplied by a factor to make the particle number size distribution smooth. The correction was done for daily data. The average correction factor was $1.05 \pm 0.11$, which means that in this size range the original inverted number concentrations increased on average by $5 \%$. The 10th, 25th, 50th, 75th and 90th percentiles of this correction factor were $0.92,0.96,1,1.1$ and 1.2 , respectively.

The model of CPC used in this study was the TSI 3772 with the $10 \mathrm{~nm}$ default cutoff diameter when the condenser temperature is at the default value of $22^{\circ} \mathrm{C}$. It was set to $10^{\circ} \mathrm{C}$ in this measurement, so the temperature difference $\Delta T$ between the saturator and the condenser was higher $\left(\Delta T>25^{\circ} \mathrm{C}\right)$, which leads to a higher supersaturation and a lower cutoff diameter. The counting efficiency of $6 \mathrm{~nm}$ particles is higher than $75 \%$ (Wiedensohler et al., 2012).

The DMPS was set up so that every time, prior to a number size distribution measurement, the DMA was by-passed and total aerosol number concentration was determined directly by the CPC (Yli-Juuti et al., 2009). The average ratio of the total particle number concentration over the diameter range $6-800 \mathrm{~nm}$ integrated from the inverted size distributions and measured directly with the CPC ( $N_{\text {DMPS }}$ and $\left.N_{\text {CPC }}\right)$ was $0.90 \pm 0.17$, and the correlation coefficient was $0.91\left(p<1 \times 10^{-6}\right)$. The 10th, 25th, 50th, 75th and 90th percentiles were $0.71,0.82,0.91,0.99$ and 1.06 , respectively. These values can indicate that data quality of the DMPS was satisfactory.

Figure A1 shows the scatter plot of $N_{\text {DMPS }}$ and $N_{\text {CPC }}$ color coded with the arithmetic mean diameter of the whole particle number size distribution $\left(\mathrm{AMD}_{6-800 \mathrm{~nm}}\right)$. The ratio of $N_{\text {DMPS }}$ to $N_{\text {CPC }}$ was low when the $\mathrm{AMD}_{6-800 \mathrm{~nm}}$ was small

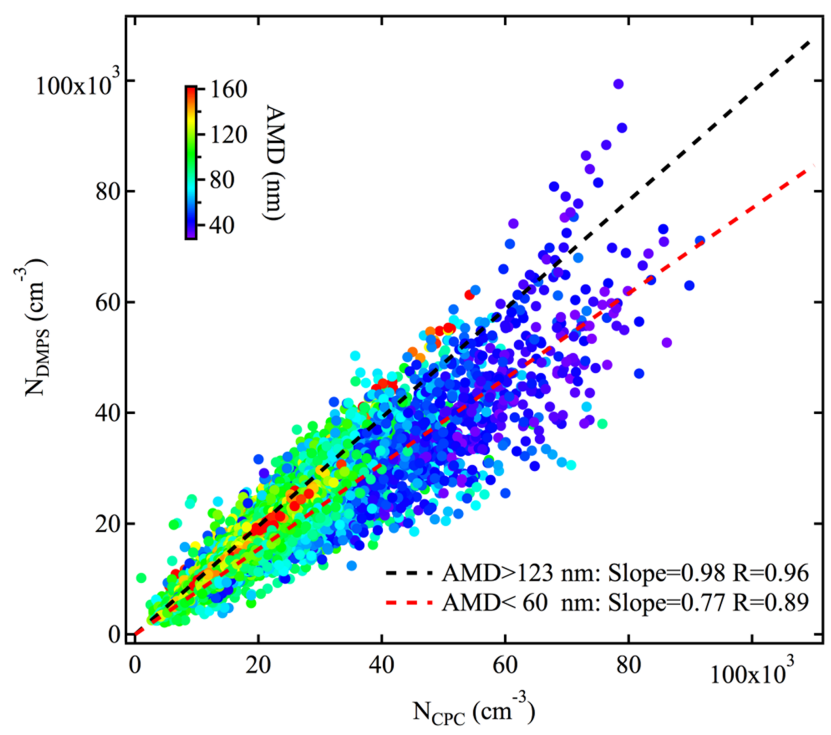

Figure A1. The scatter plot of $N_{\text {DMPS }}$ vs. $N_{\text {CPC }}$ color coded with the arithmetic mean diameter of the particle number size distribution $\left(\mathrm{AMD}_{6-800 \mathrm{~nm}}\right)$. Note: linear fits for the data when the $\mathrm{AMD}_{6-800 \mathrm{~nm}}$ is higher than $123 \mathrm{~nm}$ (90th percentiles of the $\mathrm{AMD}_{6-800 \mathrm{~nm}}$ distribution) or lower than $60 \mathrm{~nm}$ (10th percentiles of the $\mathrm{AMD}_{6-800 \mathrm{~nm}}$ distribution) are shown in the figure.

but close to 1 when the $\mathrm{AMD}_{6-800 \mathrm{~nm}}$ was large. As the small $\mathrm{AMD}_{6-800 \mathrm{~nm}}$ corresponds to new particle formation events with a high concentration of nucleation-mode particles, the lower $N_{\text {DMPS }}$-to- $N_{\text {CPC }}$ ratio suggests that the DMPS (including the inversion) may have underestimated the concentration of them. This is in line with the intercomparison study presented by Wiedensohler et al. (2012), where it was found that the largest uncertainties of the size distributions were in the nucleation mode. 
Acknowledgements. This work was supported by the National Natural Science Foundation of China (D0512/41305123, D03/41321062, and D0512/41422504). The SORPES-NJU stations were supported by the 985 program of the Ministry of Education. Part of this work was supported by the Jiangsu Provincial Science Fund for Distinguished Young Scholars awarded to A. J. Ding (no. BK20140021), by the Academy of Finland (projects 1118615 and 139656) and the European Commission via the ERC Advanced Grant ATM-NUCLE.

Edited by: W. Birmili

\section{References}

Akimoto, H.: Global air quality and pollution, Science, 302, 17161719, doi:10.1126/science.1092666, 2003.

Asmi, A., Wiedensohler, A., Laj, P., Fjaeraa, A.-M., Sellegri, K., Birmili, W., Weingartner, E., Baltensperger, U., Zdimal, V., Zikova, N., Putaud, J.-P., Marinoni, A., Tunved, P., Hansson, H.C., Fiebig, M., Kivekäs, N., Lihavainen, H., Asmi, E., Ulevicius, V., Aalto, P. P., Swietlicki, E., Kristensson, A., Mihalopoulos, N., Kalivitis, N., Kalapov, I., Kiss, G., de Leeuw, G., Henzing, B., Harrison, R. M., Beddows, D., O’Dowd, C., Jennings, S. G., Flentje, H., Weinhold, K., Meinhardt, F., Ries, L., and Kulmala, M.: Number size distributions and seasonality of submicron particles in Europe 2008-2009, Atmos. Chem. Phys., 11, 5505-5538, doi:10.5194/acp-11-5505-2011, 2011.

Birmili, W. and Wiedensohler, A.: New particls formation in the continental boundary layer: Meteorological and gas phase parameter influence, Geophys. Res. Lett., 27, 3325-3328, doi:10.1029/1999g1011221, 2000.

Birmili, W., Berresheim, H., Plass-Dülmer, C., Elste, T., Gilge, S., Wiedensohler, A., and Uhrner, U.: The Hohenpeissenberg aerosol formation experiment (HAFEX): a long-term study including size-resolved aerosol, $\mathrm{H}_{2} \mathrm{SO}_{4}, \mathrm{OH}$, and monoterpenes measurements, Atmos. Chem. Phys., 3, 361-376, doi:10.5194/acp-3-361-2003, 2003.

Boy, M. and Kulmala, M.: Nucleation events in the continental boundary layer: Influence of physical and meteorological parameters, Atmos. Chem. Phys., 2, 1-16, doi:10.5194/acp-2-1-2002, 2002.

Chameides, W. L., Luo, C., Saylor, R., Streets, D., Huang, Y., Bergin, M., and Giorgi, F.: Correlation between modelcalculated anthropogenic aerosols and satellite-derived cloud optical depths: Indication of indirect effect?, J. Geophys. Res., 107, 4085, doi:10.1029/2000JD000208, 2002.

Charlson, R. J., Schwartz, S. E., Hales, J. M., Cess, R. D., Coakley Jr., J. A., Hansen, J. E., and Hofmann, D. J.: Climate forcing by anthropogenic aerosols, Science, 255, 423-430, doi:10.1126/science.255.5043.423, 1992.

Cheng, Z., Wang, S. X., Jiang, J. K., Fu, Q. Y., Chen, C. H., Xu, B. Y., Yu, J. Q., Fu, X., and Hao, J. M.: Long-term trend of haze pollution and impact of particulate matter in the Yangtze River Delta, China, Environ. Pollut., 182, 101-110, doi:10.1016/j.envpol.2013.06.043, 2013.

Dal Maso, M., Kulmala, M., Riipinen, I., Wagner, R., Hussein, T., Aalto, P. P., and Lehtinen, K. E. J.: Formation and growth of fresh atmospheric aerosols: eight years of aerosol size distribution data from SMEAR II, Hyytiälä, Finland, Boreal Envron. Res., 10, 323-336, 2005.

Dal Maso, M., Hyvärinen, A., Komppula, M., Tunved, P., Kerminen, V.-M., Lihavainen, H., Viisanen, Y., Hansson, H.-C., and Kulmala, M.: Annual and interannual variation in boreal forest aerosol particle number and volume concentration and their connection to particle formation, Tellus, 60, 495-508, doi:10.1111/j.1600-0889.2008.00366.x, 2008.

Ding, A. J., Fu, C. B., Yang, X. Q., Sun, J. N., Zheng, L. F., Xie, Y. N., Herrmann, E., Nie, W., Petäjä, T., Kerminen, V.-M., and Kulmala, M.: Ozone and fine particle in the western Yangtze River Delta: an overview of $1 \mathrm{yr}$ data at the SORPES station, Atmos. Chem. Phys., 13, 5813-5830, doi:10.5194/acp-13-58132013, 2013a.

Ding, A. J., Fu, C. B., Yang, X. Q., Sun, J. N., Petäjä, T., Kerminen, V.-M., Wang, T., Xie, Y., Herrmann, E., Zheng, L. F., Nie, W., Liu, Q., Wei, X. L., and Kulmala, M.: Intense atmospheric pollution modifies weather: a case of mixed biomass burning with fossil fuel combustion pollution in eastern China, Atmos. Chem. Phys., 13, 10545-10554, doi:10.5194/acp-1310545-2013, 2013b.

Ding, A. J., Wang, T., and Fu, C. B.: Transport characteristics and origins of carbon monoxide and ozone in Hong Kong, South China, J. Geophys. Res., 118, 9475-9488, doi:10.1002/jgrd.50714, 2013c.

Draxler, R. R. and Hess, G. D.: An overview of the HYSPLIT 4 modeling system for trajectories dispersion and deposition, Aust. Meteorol. Mag., 47, 295-308, 1998.

Du, J. F., Cheng, T. T., Zhang, M., Chem, J. M., He, Q. S., Wang, X. M., Zhang, R. J., Tao, J., Huang, G. H., Li, X., and Zha, S. P.: Aerosol Size Spectra and Particle Formation Events at Urban Shanghai in Eastern China, Aerosol Air Qual. Res., 12, 1362 1372, doi:10.4209/aaqr.2011.12.0230, 2012.

Engler, C., Rose, D., Wehner, B., Wiedensohler, A., Brüggemann, E., Gnauk, T., Spindler, G., Tuch, T., and Birmili, W.: Size distributions of non-volatile particle residuals $\left(D_{p}<800 \mathrm{~nm}\right)$ at a rural site in Germany and relation to air mass origin, Atmos. Chem. Phys., 7, 5785-5802, doi:10.5194/acp-7-5785-2007, 2007.

$\mathrm{Fu}$, P. Q. and Kawamura, K.: Diurnal variations of polar organic tracers in summer forest aerosols: a case study of a Quercus and Picea mixed forest in Hokkaido, Japan, Geochem. J., 45, 297 308, 2011.

Gao, J., Wang, T., Zhou, X. H., Wu, W. S., and Wang, W. $X$.: Measure of aerosol number size distributions in the Yangtze River delta in China: Formation and growth of particles under polluted conditions, Atmos. Environ., 43, 829-836, doi:10.1016/j.atmosenv.2008.10.046, 2009.

Gettelman, A., Morrison, H., Terai, C. R., and Wood, R.: Microphysical process rates and global aerosol-cloud interactions, Atmos. Chem. Phys., 13, 9855-9867, doi:10.5194/acp-13-98552013, 2013.

Guo, H., Wang, D. W., Cheung, K., Ling, Z. H., Chan, C. K., and Yao, X. H.: Observation of aerosol size distribution and new particle formation at a mountain site in subtropical Hong Kong, Atmos. Chem. Phys., 12, 9923-9939, doi:10.5194/acp-12-99232012, 2012.

Hamed, A., Joutsensaari, J., Mikkonen, S., Sogacheva, L., Dal Maso, M., Kulmala, M., Cavalli, F., Fuzzi, S., Facchini, M. C., Decesari, S., Mircea, M., Lehtinen, K. E. J., and Laaksonen, 
A.: Nucleation and growth of new particles in Po Valley, Italy, Atmos. Chem. Phys., 7, 355-376, doi:10.5194/acp-7-355-2007, 2007.

Hamed, A., Korhonen, H., Sihto, S. L., Joutsensaari, J., Jarvinen, H., Petaja, T., Arnold, F., Nieminen, T., Kulmala, M., Smith, J. N., Lehtinen, K. E. J., and Laaksonen, A.: The role of relative humidity in continental new particle formation, J. Geophys. Res., 116, D03202, doi:10.1029/2010JD014186, 2011.

Heal, M. R., Kumar, P., and Harrison, R. M.: Particles, air quality, policy and health, Chem. Soc. Rev., 41, 6606-6630, doi:10.1039/C2CS35076A, 2012.

Hennigan, C. J., Westervelt, D. M., Riipinen, I., Engelhart, G. J., Lee, T., Collett Jr., J. L., Pandis, S. N., Adams, P. J., and Robinson, A. L.: New particle formation and growth in biomass burning plumes: An important source of cloud condensation nuclei, Geophys. Res. Lett., 39, L09805, doi:10.1029/2012g1050930, 2012.

Herrmann, E., Ding, A. J., Kerminen, V.-M., Petäjä, T., Yang, X. Q., Sun, J. N., Qi, X. M., Manninen, H., Hakala, J., Nieminen, T., Aalto, P. P., Kulmala, M., and Fu, C. B.: Aerosols and nucleation in eastern China: first insights from the new SORPES-NJU station, Atmos. Chem. Phys., 14, 2169-2183, doi:10.5194/acp14-2169-2014, 2014.

Huang, X.-F., He, L.-Y., Xue, L., Sun, T.-L., Zeng, L.-W., Gong, Z.-H., Hu, M., and Zhu, T.: Highly time-resolved chemical characterization of atmospheric fine particles during 2010 Shanghai World Expo, Atmos. Chem. Phys., 12, 4897-4907, doi:10.5194/acp-12-4897-2012, 2012.

IPCC: Climate Change 2013: The Physical Science Basis. Contribution of Working Group I to the Fifth Assessment Report of the Intergovernmental Panel on Climate Change, edited by: Stocker, T. F., Qin, D., Plattner, G.-K., Tignor, M., Allen, S. K., Boschung, J., Nauels, A., Xia, Y., Bex, V., and Midgley, P. M., Cambridge University Press, Cambridge, United Kingdom and New York, NY, USA, 1535 pp., doi:10.1017/CBO9781107415324, 2013.

Jimenez, J. L., Canagaratna, M. R., Donahue, N. M., Prevot, A. S. H., Zhang, Q., Kroll, J. H., DeCarlo, P. F., Allan, J. D., Coe, H., Ng, N. L., Aiken, A. C., Docherty, K. S., Ulbrich, I. M., Grieshop, A. P., Robinson, A. L., Duplissy, J., Smith, J. D., Wilson, K. R., Lanz, V. A., Hueglin, C., Sun, Y. L., Tian, J., Laaksonen, A., Raatikainen, T., Rautiainen, J., Vaattovaara, P., Ehn, M., Kulmala, M., Tomlinson, J. M., Collins, D. R., Cubison, M. J., Dunlea, E. J., Huffman, J. A., Onasch, T. B., Alfarra, M. R., Williams, P. I., Bower, K., Kondo, Y., Schneider, J., Drewnick, F., Borrmann, S., Weimer, S., Demerjian, K., Salcedo, D., Cottrell, L., Griffin, R., Takami, A., Miyoshi, T., Hatakeyama, S., Shimono, A., Sun, J. Y., Zhang, Y. M., Dzepina, K., Kimmel, J. R., Sueper, D., Jayne, J. T., Herndon, S. C., Trimborn, A. M., Williams, L. R., Wood, E. C., Middlebrook, A. M., Kolb, C. E., Baltensperger, U., and Worsnop, D. R.: Evolution of organic aerosols in the atmosphere, Science, 326, 1525-1529, doi:10.1126/science.1180353, 2009.

Kamens, R. M., Zhang, H. F., Chen, E. H., Zhou, Y., Parikh, H. M., Wilson, R. L., Galloway, K. E., and Rosen, E. P.: Secondary organic aerosol formation from toluene in an atmospheric hydrocarbon mixture: Water and particle seed effects, Atmos. Environ., 45, 2324-2334, doi:10.1016/j.atmosenv.2010.11.007, 2011.

Kerminen, V.-M., Lihavainen, H., Komppula, M., Viisanen, Y., and Kulmala, M.: Direct observational evidence linking atmospheric aerosol formation and cloud droplet activation, Geophys. Res. Lett., 32, L14803, doi:10.1029/2005g1023130, 2005.

Kerminen, V.-M., Paramonov, M., Anttila, T., Riipinen, I., Fountoukis, C., Korhonen, H., Asmi, E., Laakso, L., Lihavainen, H., Swietlicki, E., Svenningsson, B., Asmi, A., Pandis, S. N., Kulmala, M., and Petäjä, T.: Cloud condensation nuclei production associated with atmospheric nucleation: a synthesis based on existing literature and new results, Atmos. Chem. Phys., 12, 1203712059, doi:10.5194/acp-12-12037-2012, 2012.

Kivekäs, N., Sun, J., Zhan, M., Kerminen, V.-M., Hyvärinen, A., Komppula, M., Viisanen, Y., Hong, N., Zhang, Y., Kulmala, M., Zhang, X.-C., Deli-Geer, and Lihavainen, H.: Long term particle size distribution measurements at Mount Waliguan, a highaltitude site in inland China, Atmos. Chem. Phys., 9, 5461-5474, doi:10.5194/acp-9-5461-2009, 2009.

Komppula, M., Lihavainen, H., Hyvarinen, A. P., Kerminen, V.-M., Panwar, T. S., Sharma, V. P., andVisanen, Y.: Physical properties of aerosol particles at a Himalayan background site in India, J.Geophys. Res., 114, D12202, doi:10.1029/2008jd011007, 2009.

Kulmala, M. and Kerminen, V.-M.: On the formation and growth of atmospheric nanoparticles, Atmos. Res., 90, 132-150, doi:10.1016/j.atmosres.2008.01.005, 2008.

Kulmala, M., Vehkamaki, H., Petäjä, T., Dal Maso, M., Lauri, A., Kerminen, V.-M., Birmili, W., and McMurry, P. H.: Formation and growth rates of ultrafine atmospheric particles: a review of observations, J. Aerosol Sci., 35, 143-176, doi:10.1016/j.jaerosci.2003.10.003, 2004.

Kulmala, M., Petäjä, T., Nieminen, T., Sipilä, M., Manninen, H. E., Lehtipalo, K., Dal Maso, M., Aalto, P. P., Junninen, H., Paasonen, P., Riipinen, I., Lehtinen, K. E. J., Laaksonen, A., and Kerminen, V.-M.: Measurement of the nucleation of atmospheric aerosol particles, Nat. Protoc., 7, 1651-1667, doi:10.1038/nprot.2012.091, 2012.

Kulmala, M., Kontkanen, J., Junninen, H., Lehtipalo, K., Manninen, H. E., Nieminen, T., Petäjä, T., Sipila, M., Schobesberger, S., Rantala, P., Franchin, A., Jokinen, T., Jarvinen, E., Aijala, M., Kangasluoma, J., Hakala, J., Aalto, P. P., Paasonen, P., Mikkila, J., Vanhanen, J., Aalto, J., Hakola, H., Makkonen, U., Ruuskanen, T., Mauldin, R. L., Duplissy, J., Vehkamaki, H., Back, J., Kortelainen, A., Riipinen, I., Kurten, T., Johnston, M. V., Smith, J. N., Ehn, M., Mentel, T. F., Lehtinen, K. E. J., Laaksonen, A., Kerminen, V.-M., and Worsnop, D. R.: Direct Observation of Atmospheric Aerosol Nucleation, Science, 339, 943-946, doi:10.1126/science.1227385, 2013.

Kulmala, M., Petäjä, T., Ehn, M., Thornton, J., Sipilä, M., Worsnop, D. R., and Kerminen, V.-M.: Chemistry of atmospheric nucleation: On the recent advances on precursor characterization and atmospheric cluster composition in connection with atmospheric particle formation, Annu. Rev. Phys. Chem., 65, 21-37, doi:10.1146/annurev-physchem-040412-110014, 2014.

Laakso, L., Petäjä, T., Lehtinen, K. E. J., Kulmala, M., Paatero, J., Hõrrak, U., Tammet, H., and Joutsensaari, J.: Ion production rate in a boreal forest based on ion, particle and radiation measurements, Atmos. Chem. Phys., 4, 1933-1943, doi:10.5194/acp-41933-2004, 2004.

Laakso, L., Laakso, H., Aalto, P. P., Keronen, P., Petäjä, T., Nieminen, T., Pohja, T., Siivola, E., Kulmala, M., Kgabi, N., Molefe, M., Mabaso, D., Phalatse, D., Pienaar, K., and Kermi- 
nen, V.-M.: Basic characteristics of atmospheric particles, trace gases and meteorology in a relatively clean Southern African Savannah environment, Atmos. Chem. Phys., 8, 4823-4839, doi:10.5194/acp-8-4823-2008, 2008.

Lebo, Z. J. and Feingold, G.: On the relationship between responses in cloud water and precipitation to changes in aerosol, Atmos. Chem. Phys., 14, 11817-11831, doi:10.5194/acp-1411817-2014, 2014.

Li, L., Chen, C. H., Fu, J. S., Huang, C., Streets, D. G., Huang, H. Y., Zhang, G. F., Wang, Y. J., Jang, C. J., Wang, H. L., Chen, Y. R., and Fu, J. M.: Air quality and emissions in the Yangtze River Delta, China, Atmos. Chem. Phys., 11, 16211639, doi:10.5194/acp-11-1621-2011, 2011.

Li, X. H., Duan, L., Wang, S. X., Duan, J. C., Guo, X. M., Yi, H. H., Hu, J. N., Li, C., and Hao, J. M.: Emission characteristics of particulate matter from rural household biofuel combustion in China, Energy Fuels, 21, 845-851, doi:10.1021/ef060150g, 2007.

Liu, S., Hu, M., Wu, Z. J., Wehner, B., Wiedensohler, A., and Cheng, Y. F.: Aerosol number size distribution and new particle formation at a rural/coastal site in Pearl River Delta (PRD) of China, Atmos. Environ., 42, 6275-6283, doi:10.1016/j.atmosenv.2008.01.063, 2008.

Malm, W. C., Sisler, J. F., Huffman, D., Eldred, R. A., and Cahill, T. A.: Spatial and seasonal trends in particle concentration and optical extinction in the United-States, J. Geophys. Res., 99, 13471370, doi:10.1029/93jd02916, 1994.

Manninen, H. E., Nieminen, T., Asmi, E., Gagné, S., Häkkinen, S., Lehtipalo, K., Aalto, P., Vana, M., Mirme, A., Mirme, S., Hõrrak, U., Plass-Dülmer, C., Stange, G., Kiss, G., Hoffer, A., Töro, N., Moerman, M., Henzing, B., de Leeuw, G., Brinkenberg, M., Kouvarakis, G. N., Bougiatioti, A., Mihalopoulos, N., O'Dowd, C., Ceburnis, D., Arneth, A., Svenningsson, B., Swietlicki, E., Tarozzi, L., Decesari, S., Facchini, M. C., Birmili, W., Sonntag, A., Wiedensohler, A., Boulon, J., Sellegri, K., Laj, P., Gysel, M., Bukowiecki, N., Weingartner, E., Wehrle, G., Laaksonen, A., Hamed, A., Joutsensaari, J., Petäjä, T., Kerminen, V.-M., and Kulmala, M.: EUCAARI ion spectrometer measurements at 12 European sites - analysis of new particle formation events, Atmos. Chem. Phys., 10, 7907-7927, doi:10.5194/acp-10-79072010, 2010.

Menon, S., Hansen, J., Nazarenko, L., and Luo, Y. F.: Climate effects of black carbon aerosols in China and India, Science, 297, 2250-2253, doi:10.1126/science.1075159, 2002.

Mikkonen, S., Romakkaniemi, S., Smith, J. N., Korhonen, H., Petäjä, T., Plass-Duelmer, C., Boy, M., McMurry, P. H., Lehtinen, K. E. J., Joutsensaari, J., Hamed, A., Mauldin III, R. L., Birmili, W., Spindler, G., Arnold, F., Kulmala, M., and Laaksonen, A.: A statistical proxy for sulphuric acid concentration, Atmos. Chem. Phys., 11, 11319-11334, doi:10.5194/acp-11-11319-2011, 2011.

Nie, W., Ding, A. J., Wang, T., Kerminen, V.-M., George, C., Xue, L. K., Wang, W. X., Zhang, Q. Z., Petäjä, T., Qi, X. M., Gao, X. M., Wang, X. F., Yang, X. Q., Fu, C. B., and Kulmala, M.: Polluted dust promotes new particle formation and growth, Scientific Reports, 4, 6634, doi:10.1038/srep06634, 2014.

Nie, W., Ding, A. J., Xie, Y. N., Xu, Z., Mao, H., Kerminen, V.M., Zheng, L. F., Qi, X. M., Huang, X., Yang, X.-Q., Sun, J. N., Herrmann, E., Petäjä, T., Kulmala, M., and Fu, C. B.: Influence of biomass burning plumes on HONO chemistry in eastern China,
Atmos. Chem. Phys., 15, 1147-1159, doi:10.5194/acp-15-11472015, 2015.

Nieminen, T., Asmi, A., Dal Maso, M., Aalto, P. P., Keronen, P., Petäjä, T., Kulmala, M., and Kerminen, V.-M.: Trends in atmospheric new-particle formation: 16 years of observations in a boreal-forest environment, Boreal Environ. Res., 19, 191-214, 2014.

Peng, J. F., Hu, M., Wang, Z. B., Huang, X. F., Kumar, P., Wu, Z. J., Guo, S., Yue, D. L., Shang, D. J., Zheng, Z., and He, L. Y.: Submicron aerosols at thirteen diversified sites in China: size distribution, new particle formation and corresponding contribution to cloud condensation nuclei production, Atmos. Chem. Phys., 14, 10249-10265, doi:10.5194/acp-14-10249-2014, 2014.

Pope, C. A., Burnett, R. T., Thun, M. J., Calle, E. E., Krewski, D., Ito, K., and Thurston, G. D.: Lung cancer, cardiopulmonary mortality, and long term exposure to fine particulate air pollution, JAMA-J. Am. Med. Assoc., 287, 1132-1141, doi:10.1001/jama.287.9.1132, 2002.

Qian, Y., Leung, L. R., Ghan, S. J., and Giorgi, F.: Regional climate effects of aerosols over China: modeling and observation, Tellus B, 55, 914-934, doi:10.1046/j.1435-6935.2003.00070.x,2003.

Raes, F., Van Dingenen, R., Vignati, E., Wilson, J., Putaud, J.P., Seinfeld, J. H., and Adams, P.: Formation and cycling of aerosols in the global troposphere, Atmos. Environ., 34, 42154240, doi:10.1016/S1352-2310(00)00239-9, 2000.

Rao, S., Chirkov, V., Dentener, F., Van Dingenen, R., Pachauri, S., Purohit, P., Amann, M., Heyes, C., Kinney, P., Kolp, P., Klimont, Z., Riahi, K., and Schoepp, W.: Environmental modeling and methods for estimation of the global health impacts of air pollution, Environ. Model. Assess., 17, 613-622, doi:10.1007/s10666-012-9317-3, 2012.

Reid, J. S., Koppmann, R., Eck, T. F., and Eleuterio, D. P.: A review of biomass burning emissions part II: intensive physical properties of biomass burning particles, Atmos. Chem. Phys., 5, 799825, doi:10.5194/acp-5-799-2005, 2005.

Rose, C., Sellegri, K., Velarde, F., Moreno, I., Ramonet, M., Weinhold, K., Krejci, R., Andrade, M., Wiedensohler, A., and Laj, P.: Frequent nucleation events at the high altitude station of Chacaltaya (5240 m a.s.1.), Bolivia, Atmos. Environ., 102, 18-29, doi:10.1016/j.atmosenv.2014.11.015, 2015.

Shen, X. J., Sun, J. Y., Zhang, Y. M., Wehner, B., Nowak, A., Tuch, T., Zhang, X. C., Wang, T. T., Zhou, H. G., Zhang, X. L., Dong, F., Birmili, W., and Wiedensohler, A.: First long-term study of particle number size distributions and new particle formation events of regional aerosol in the North China Plain, Atmos. Chem. Phys., 11, 1565-1580, doi:10.5194/acp-11-15652011, 2011.

Sihto, S.-L., Mikkilä, J., Vanhanen, J., Ehn, M., Liao, L., Lehtipalo, K., Aalto, P. P., Duplissy, J., Petäjä, T., Kerminen, V.-M., Boy, M., and Kulmala, M.: Seasonal variation of CCN concentrations and aerosol activation properties in boreal forest, Atmos. Chem. Phys., 11, 13269-13285, doi:10.5194/acp-11-13269-2011, 2011.

Stanier, C. O., Khlysyov, A. Y., and Pandis, S. N.: Ambient aerosol size distributions and number concentrations measured during the Pittsburgh Air Quality Study (PAQS), Atmos. Environ., 38, 3275-3284, doi:10.1016/j.atmosenv.2004.03.020, 2004.

Tie, X. X. and Cao, J. J.: Aerosol pollution in China: Present and future impact on environment, Particuology, 7, 426-431, doi:10.1016/j.partic.2009.09.003, 2009. 
Tunved, P., Nilsson, E. D., Hansson, H.-C., and Strom, J.: Aerosol characteristics of air masses in northern Europe: influences of location, transport, sinks, and sources, J. Geophys. Res., 110, D07201, doi:10.1029/2004jd005085, 2005.

Tunved, P., Hansson, H.-C., Kerminen, V.-M., Ström, J., Dal Maso, M., Lihavainen, H., Viisanen, Y., Aalto, P. P., Komppula, M., and Kulmala, M.: High natural aerosol loading over boreal forests, Science, 312, 261-263, 2006.

Vakkari, V., Beukes, J. P., Laakso, H., Mabaso, D., Pienaar, J. J., Kulmala, M., and Laakso, L.: Long-term observations of aerosol size distributions in semi-clean and polluted savannah in South Africa, Atmos. Chem. Phys., 13, 1751-1770, doi:10.5194/acp13-1751-2013, 2013.

Vakkari, V., Kerminen, V.-M., Beukes, J. P., Titta, P., van Zyl, P. G., Josipovic, M., Venter, A. D., Laars, K., Worsnop, D. R., Kulmala, M., and Laakso, L.: Rapid changes in biomass burning aerosols by atmospheric oxidation, Geophys. Res. Lett., 41, 2644-2651, doi:10.1002/2014g1059396, 2014.

Wang, H. L., Zhu, B., Shen, L. J., An, J. L., Yin, Y., and Kang, H. Q.: Number size distribution of aerosols at Mt. Huang and Nanjing in the Yangtze River Delta, China: Effects of air masses and characteristics of new particle formation, Atmos. Res., 150, 42-56, doi:10.1016/j.atmosres.2014.07.020, 2014.

Wang, Y. G., Hopke, P. K., Chalupa, D. C., and Utell, M. J.: Long-term study of urban ultrafine particles and other pollutants, Atmos. Environ., 45, 7672-7680, doi:10.1016/j.atmosenv.2010.08.022, 2011.

Wehner, B., Birmili, W., Ditas, F., Wu, Z., Hu, M., Liu, X., Mao, J., Sugimoto, N., and Wiedensohler, A.: Relationships between submicrometer particulate air pollution and air mass history in Beijing, China, 2004-2006, Atmos. Chem. Phys., 8, 6155-6168, doi:10.5194/acp-8-6155-2008, 2008.

Wiedensohler, A., Cheng, Y. F., Nowak, A., Wehner, B., Achtert, P., Berghof, M., Birmili, W., Wu, Z. J., Hu, M., Zhu, T., Takegawa, N., Kita, K., Kondo, Y., Lou, S. R., Hofzumahaus, A., Holland, F., Wahner, A., Gunthe, S. S., Rose, D., Su, H., and Pöschl, U.: Rapid aerosol particle growth and increase of cloud condensation nucleus activity by secondary aerosol formation and condensation: A case study for regional air pollution in northeastern China, J. Geophys. Res., 114, D00G08, doi:10.1029/2008jd010884, 2009.

Wiedensohler, A., Birmili, W., Nowak, A., Sonntag, A., Weinhold, K., Merkel, M., Wehner, B., Tuch, T., Pfeifer, S., Fiebig, M., Fjäraa, A. M., Asmi, E., Sellegri, K., Depuy, R., Venzac, H., Villani, P., Laj, P., Aalto, P., Ogren, J. A., Swietlicki, E., Williams, P., Roldin, P., Quincey, P., Hüglin, C., Fierz-Schmidhauser, R., Gysel, M., Weingartner, E., Riccobono, F., Santos, S., Grüning, C., Faloon, K., Beddows, D., Harrison, R., Monahan, C., Jennings, S. G., O'Dowd, C. D., Marinoni, A., Horn, H.-G., Keck, L., Jiang, J., Scheckman, J., McMurry, P. H., Deng, Z., Zhao, C. S., Moerman, M., Henzing, B., de Leeuw, G., Löschau, G., and Bastian, S.: Mobility particle size spectrometers: harmonization of technical standards and data structure to facilitate high quality long-term observations of atmospheric particle number size distributions, Atmos. Meas. Tech., 5, 657-685, doi:10.5194/amt5-657-2012, 2012.
Woo, K. S., Chen, D. R., Pui, D. Y. H., and McMurry, P. H.: Measurement of Atlanta aerosol size distributions: Observations of ultrafine particle events, Aerosol Sci. Tech., 34, 75-87, doi:10.1080/027868201300082049, 2001.

Wu, Y.-X., Yin, Y., Gu, X.-S., and Tan, H.-B.: An observational study of the hygroscopic properties of aerosols in north suburb of Nanjing, China Environ. Sci., 34, 1938-1949, 2014.

Wu, Z. J., Hu, M., Liu, S., Wehner, B., Bauer, S., Maßling, A., Wiedensohler, A., Petäjä, T., Dal Maso, M., and Kulmala, M.: New particle formation in Beijing, China: Statistical analysis of a 1-year data set, J. Geophys. Res., 112, D09209, doi:10.1029/2006jd007406, 2007.

Wu, Z. J., Hu, M., Lin, P., Liu, S., Wehner, B., and Wiedensohler, A.: Particle number size distribution in the urban atmosphere of Beijing, China, Atmos. Environ., 42, 7967-7980, doi:10.1016/j.atmosenv.2008.06.022, 2008.

Yli-Juuti, T., Riipinen, I., Aalto, P. P., Nieminen, T., Ugent, W. M., Janssens, I. A., Claeys, M., Salma, I., Ocskay, R., Hoffer, A., Imre, K., and Kulmala, M.: Characteristics of new particle formation events and cluster ions at K-Puszta, Hungry, Boreal Environ. Res., 14, 683-698, 2009.

Yli-Juuti, T., Nieminen, T., Hirsikko, A., Aalto, P. P., Asmi, E., Hõrrak, U., Manninen, H. E., Patokoski, J., Dal Maso, M., Petäjä, T., Rinne, J., Kulmala, M., and Riipinen, I.: Growth rates of nucleation mode particles in Hyytiälä during 20032009: variation with particle size, season, data analysis method and ambient conditions, Atmos. Chem. Phys., 11, 12865-12886, doi:10.5194/acp-11-12865-2011, 2011.

Young, L.-H., Benson, D. R., Montanaro, W. M., Lee, S.-H., Pan, L. L., Rogers, D. C., Jensen, J., Stith, J. L., Davis, C. A., Campos, T. L., Bowman, K. P., Cooper, W. A., and Lait, L. R.: Enhanced new particle formation observed in the northern midlatitude tropopause region, J. Geophys. Res.-Atmos., 112, D10218, doi:10.1029/2006JD008109, 2007.

Zhang, Q., Jimenez, J. L., Canagaratna, M. R., Allan, J. D., Coe, H., Ulbrich, I., Alfarra, M. R., Takami, A., Middlebrook, A. M., Sun, Y. L., Dzepina, K., Dunlea, E., Docherty, K., DeCarlo, P. F., Salcedo, D., Onasch, T., Jayne, J. T., Miyoshi, T., Shimono, A., Hatakeyama, S., Takegawa, N., Kondo, Y., Schneider, J., Drewnick, F., Borrmann, S., Weimer, S., Demerjian, K., Williams, P., Bower, K., Bahreini, R., Cottrell, L., Griffin, R. J., Rautiainen, J., Sun, J. Y., Zhang, Y. M., and Worsnop, D. R.: Ubiquity and dominance of oxygenated species in organic aerosols in anthropogenically-influenced Northern Hemisphere multitudes, Geophys. Res. Lett., 34, L13801, doi:10.1029/2007GL029979, 2007.

Zhang, Q., Streets, D. G., Carmichael, G. R., He, K. B., Huo, H., Kannari, A., Klimont, Z., Park, I. S., Reddy, S., Fu, J. S., Chen, D., Duan, L., Lei, Y., Wang, L. T., and Yao, Z. L.: Asian emissions in 2006 for the NASA INTEX-B mission, Atmos. Chem. Phys., 9, 5131-5153, doi:10.5194/acp-9-5131-2009, 2009. 